\title{
GLACIAL GEOLOGY AND TILL GEOCHEMISTRY IN ORE EXPLORATION IN THE TERVOLA AREA, SOUTHERN FINNISH LAPLAND
}

\author{
PERTTI SARALA, VESA PEURANIEMI and RISTO AARIO
}

SARALA, PERTTI, PEURANIEMI, VESA and AARIO, RISTO 1998. Glacial geology and till geochemistry in ore exploration in the Tervola area, southern Finnish Lapland. Bulletin of the Geological Society of Finland 70, Parts 1-2, $19-41$.

Glacial geology and till geochemistry were studied in an ore exploration project in the Palaeoproterozoic Peräpohja Schist Belt in the Tervola area of southern Finnish Lapland. The starting point for the exploration were numerous Au-Cu-rich erratics, the source rock of which was unknown. The mapping of the glacial landforms was based on aerial photo interpretation. The structure, texture, lithology and geochemistry of the till were studied using test pits. Three sieved fractions together with a heavy mineral fraction of the till were analyzed chemically.

The glacial landforms of the area include cover and ground moraines, drumlins, flute ridges and Rogen moraines. The ridges of the Rogen moraine were found to be composed of three different till beds. The surficial parts of the Rogen ridges showed very short transport distance, whilst the lower till was of more distant derivation.

Gold and $\mathrm{Cu}$ contents in the till are above their regional background levels in every analyzed fraction in the two case study areas of Petäjävaara and Vammavaara. High metal contents in till are associated with basic volcanic rocks and their contact zones with quartzite in bedrock. Metal anomalies in till are usually very sharp-contrasted and dilute quickly with increasing distance from the source rock. The most useful indicator elements in till geochemistry, in addition to $\mathrm{Au}$, are $\mathrm{Cu}, \mathrm{Te}$ and $\mathrm{Co}$. The combination of careful studies of glacial geology and till geochemistry proved to be a powerful means in locating source rock of glacially transported ore boulders in this area. As a result of the exploration, $\mathrm{Cu}-\mathrm{Au}$ mineralization was localized at Petäjävaara.

Key words: mineral exploration, geochemical methods, till, stratigraphy, geochemistry, gold, copper, pathfinders, heavy minerals, glacial transport, erratics, Tervola, Finland

Pertti Sarala, Vesa Peuraniemi and Risto Aario: Institute of Geosciences, University of Oulu, PL 3000, 90401 OULU, Finland.

E-mail:vesa.peuraniemi@oulu.fi 


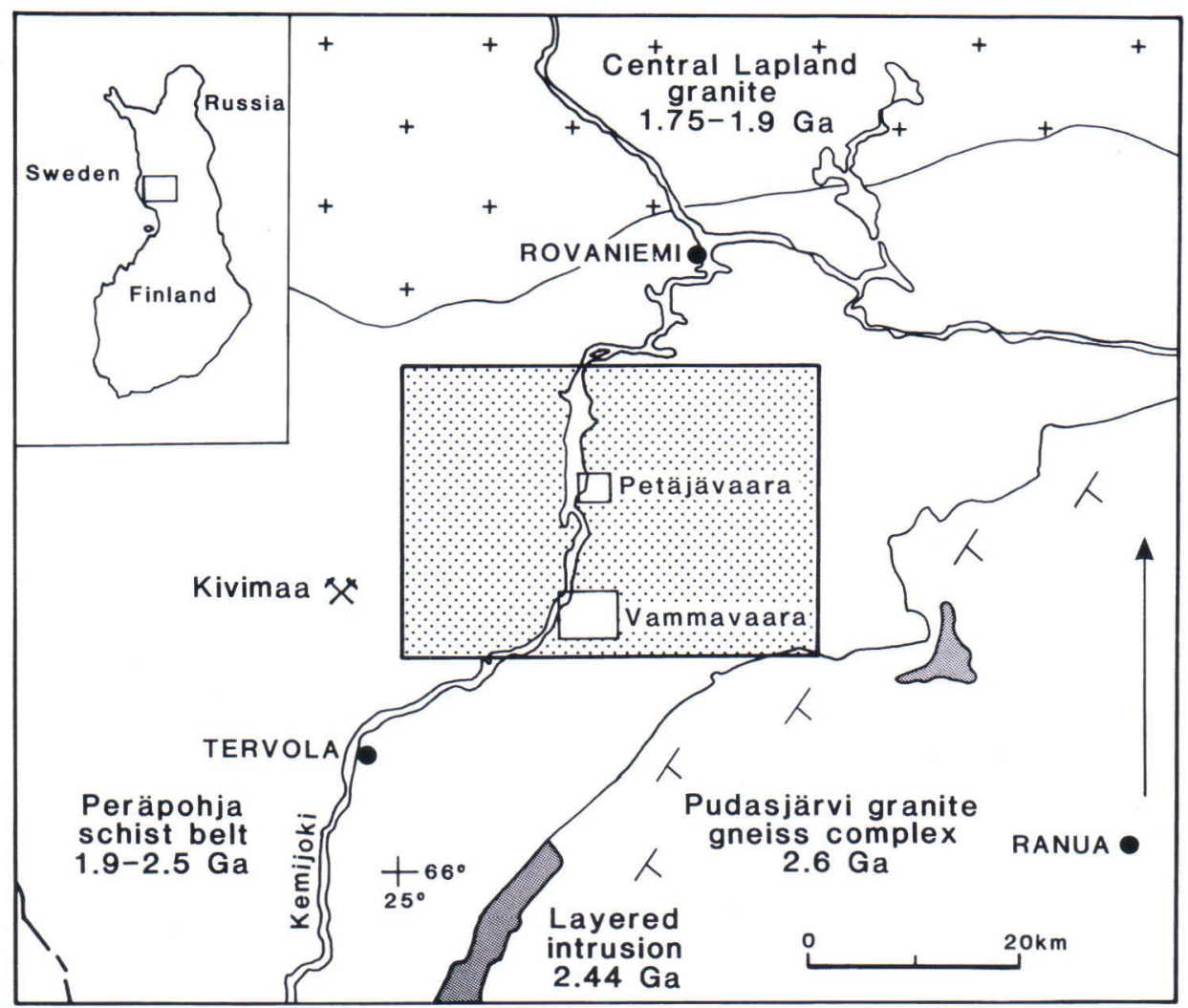

Fig. 1. The location of the study area in the Peräpohja Schist Belt.

\section{INTRODUCTION}

Ore exploration has been quite intensive in the area of the Peräpohja Schist Belt during the last decades. Many small mineralizations have been discovered (e.g. Mikkola 1947, Peuraniemi 1982, Äyräs 1991), but only one, a Cu-Au deposit in Kivimaa (Rouhunkoski \& Isokangas 1974) has been mined so far (Fig. 1). Gold exploration in the greenstone and schist belts in Finland has intensified prospecting also in the Peräpohja Schist Belt.

Till geochemistry is an effective method in prospecting for metal mineralizations in glaciated areas. Different sampling densities, fractions and soil horizons have been used in Au exploration e.g. by Shilts (1984), Bloom and Steel (1989), Gleeson et al. (1989), McClenaghan (1992), Nichol et al. (1992), Hartikainen and Nurmi (1993), and Sibbick and Fletcher (1993). The importance of knowledge on glacial history and till stratigraphy in prospecting has been stressed by Campbell and Schreiner (1989), Hirvas (1989), Hirvas and Nenonen (1990), Aario and Peuraniemi (1992), and McClenaghan et al. (1992).

Delineation of the geochemical provinces in Finland is possible on the basis of regional till geochemical maps (Koljonen 1992, Salminen 1995, Salminen \& Tarvainen 1995). Maps of the regional till geochemistry of northern Finland (sampling density $1 / 30 \mathrm{~km}^{2}$ ) show that the study area is a part of a SW-NE trending $\mathrm{Cu}$-anomalous zone (Fig. 2a). Gold, instead, has no anomalous values in the study area (Fig. 2b). Both maps are based on the work of the so-called Nordkalott Project (Bølviken et al. 1986). A more detailed (sampling density $1 / 4 \mathrm{~km}^{2}$ ) regional till geochemistry (Koivisto 1992) shows several $\mathrm{Cu}$ and $\mathrm{Au}$ anomalous samples in the study area (Fig. 3). 

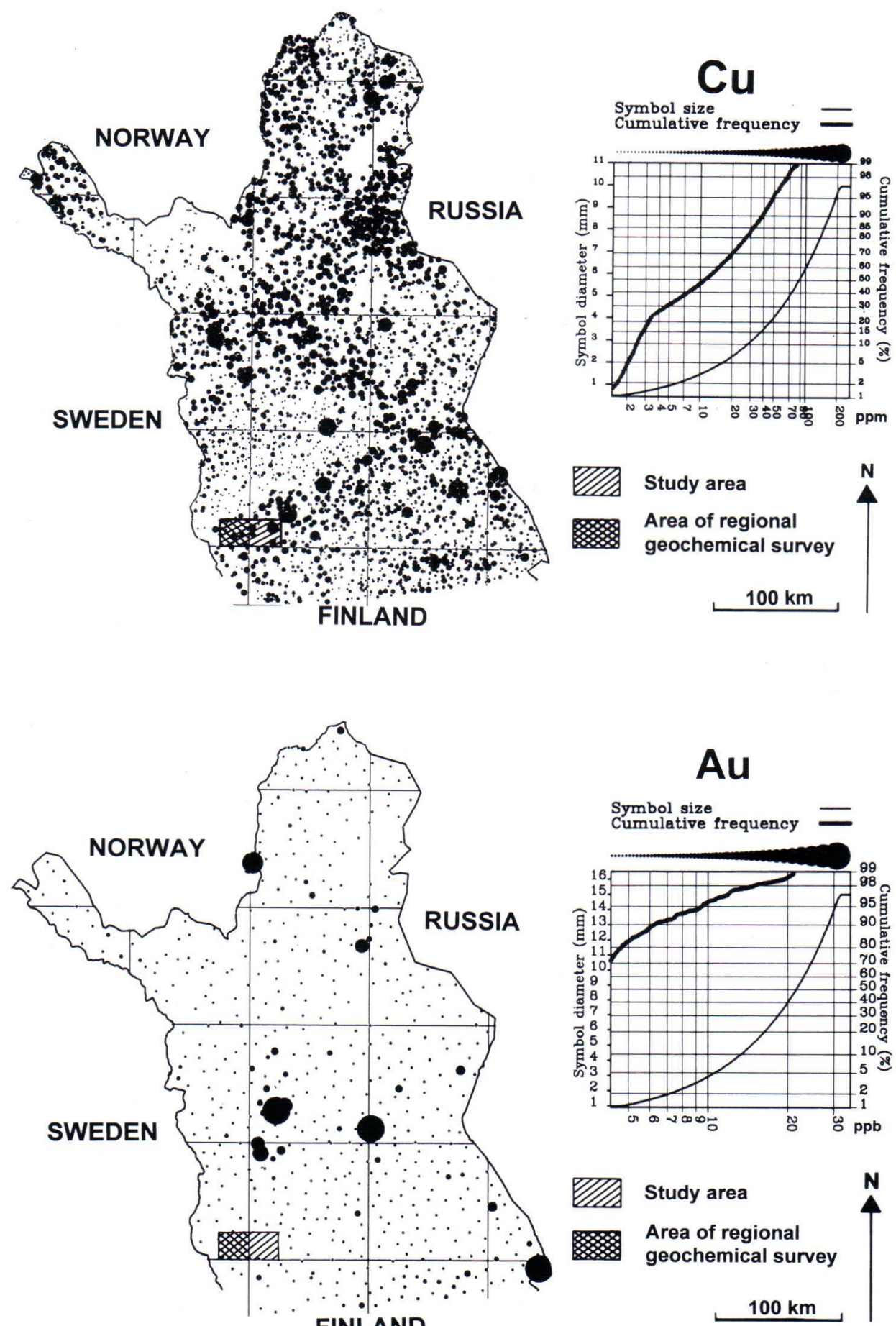

Fig. 2. The distribution of a) $\mathrm{Cu}$ and b) Au in till in northern Finland. Sampling density is one sample per $30 \mathrm{~km}^{2}$. Number of samples is 5400 in Cu map and 1036 in Au map. Modified from the maps of the Nordkalott Project (Bølviken et al. 1986). 

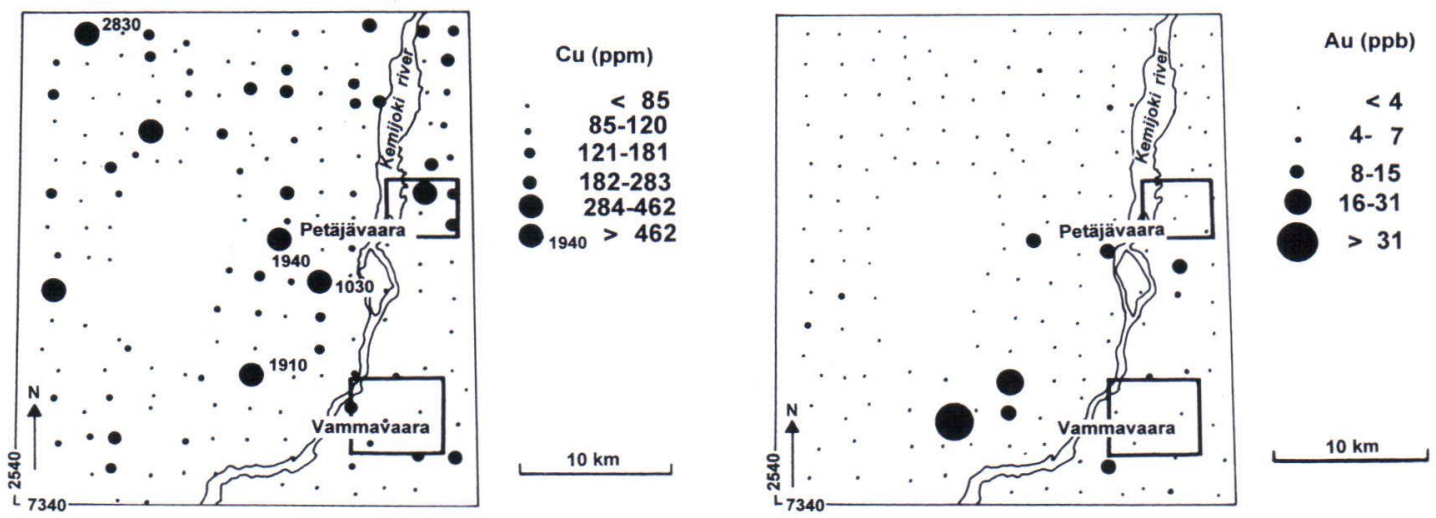

Fig. 3. The distribution of a) $\mathrm{Cu}$ and b) $\mathrm{Au}$ in till in the central part of the Peräpohja Schist Belt. Sampling density is one sample per $4 \mathrm{~km}^{2}$. Slightly modified from the map of Koivisto (1992).

Numerous erratics (basic volcanic rock and/or quartzite) containing pyrite, chalcopyrite and $\mathrm{Au}$ have been the starting point for this study. The aim has been to decipher the glacial geology of the area in order to shed light on the ice transport directions and distances. The ultimate goal has been to locate the source rocks of the mineralized erratics. Detailed studies were concentrated in the Petäjävaara and Vammavaara areas (Fig. 1); field work was done during the years 1992-1995.

\section{GEOLOGICAL SETTING}

\section{Bedrock geology}

The study area is a part of the Palaeoproterozoic Peräpohja Schist Belt (Fig. 1). The schists are bordered in the south by the Archaean Pudasjärvi Granite Gneiss Complex and in the north by the Palaeoproterozoic Central Lapland Granite Complex. Layered mafic intrusions occur between the schist belt and granite gneiss complex. According to Perttunen $(1989,1991)$, the supracrustal schist belt contains three volcanic formations separated by quartzite-dominated sedimentary formations that typically consist of quartzite and dolomite beds. Volcanic rocks are composed of tholeiitic basalts or tuffitic rocks. Quartzites are usually cut by albite diabases. Other rock types are conglomerate, phyllite and mica schist. The schist belt has been folded along an E-W trending fold axis.

\section{Quaternary geology}

Quaternary geology in southern Finnish Lapland has been studied since Okko's $(1941,1944)$ work on grain size properties and lithology of till. The earliest study on till stratigraphy in the area was made by Korpela (1969). He found two different ice flow phases, the younger one from the west, and the older one from the northwest; and between the respective tills there were sorted sediments and organic matter suggested to belong to the Peräpohjola Interstadial. Hirvas et al. (1977) further studied the till stratigraphy in North and Central Finnish Lapland and had also some observations from southern Lapland. In his till stratigraphy, Hirvas (1990) suggested six different till units numbered I-VI from the youngest to oldest. Units I-III are of Weichselian age and the Peräpohjola Interstadial was interpreted as lying between units II and III. Units II and III are accordingly correlated with the upper and lower till beds of Korpela (1969). Units IV-VI are older and they have been found mainly in the former ice divide zone in Central Lapland, but not in the present study area. The latest stratigraphical studies have been made by the present authors on the northern side of the village of Tervola, where the Sihtuuna moraine ridges were described (Aario et al. 1997).

The final retreat of the ice sheet from northern Finland took place at about 9000 B.P. (Hyyppä 1966, Ignatius et al. 1980). During deglaciation, 


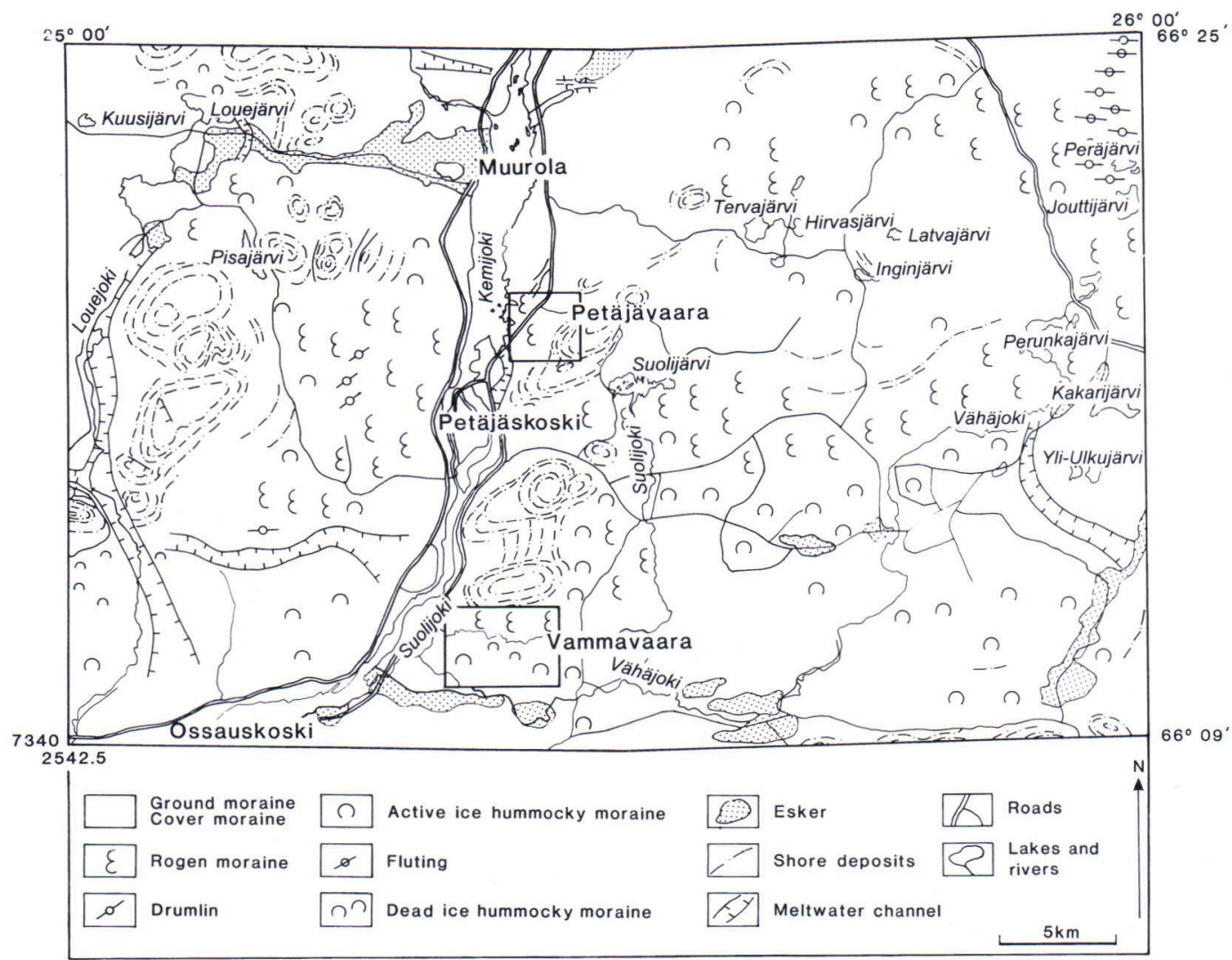

Fig. 4. Glacial geology of the study area. Youngest ice flow direction has been from west to east.

the proglacial Ancylus Ice Lake left its marks on the slopes of the highest hills in western and southern Lapland. The highest shore lines are now seen on the level of about $215 \mathrm{~m}$ a.s.1. (Eronen 1974). The shore deposits under the level of $100 \mathrm{~m}$ belong to the Litorina Sea phase.

An aerial photo interpretation of the study area (Fig. 4) shows that till is the most common surficial deposit occurring as various morainic landforms and their assemblages (Aario et al. 1996, Sarala et al. 1996). Ground moraine having only very gently undulating topography occurs mostly in the western and southern parts of the area. The thickness of till is 5-8 $\mathrm{m}$ in low-lying areas and 1-3 $\mathrm{m}$ on higher ground. In places, ground moraine passes laterally into active ice hummocks of low relief. Till is quite thin in the northern and southeastern parts and has been interpreted to be cover moraine. It drapes the bedrock topography (Aario 1977).

Rogen moraine is the most dominant landscape type. It was formed during a younger ice flow from the west. The Rogen areas consist here both of hummocks and ridges (Fig 5), which commonly have a boulder-strewn surface. The dimensions of the ridges are variable: the length is $100-500 \mathrm{~m}$, width $50-100 \mathrm{~m}$ and height $2-10 \mathrm{~m}$. Three areas dominated by Rogen moraines have been delineated. The first is at Petäjäskoski, where the main area occurs on the west side of the Kemijoki river and continues to the east as far as the Petäjävaara case study area (Fig. 6). The second area begins from Suolijärvi and continues as a narrow chain up to Perunkajärvi. The third area is in the northeastern part of the study area (Peräjärvi-Jouttijärvi). Rogen moraine is common 


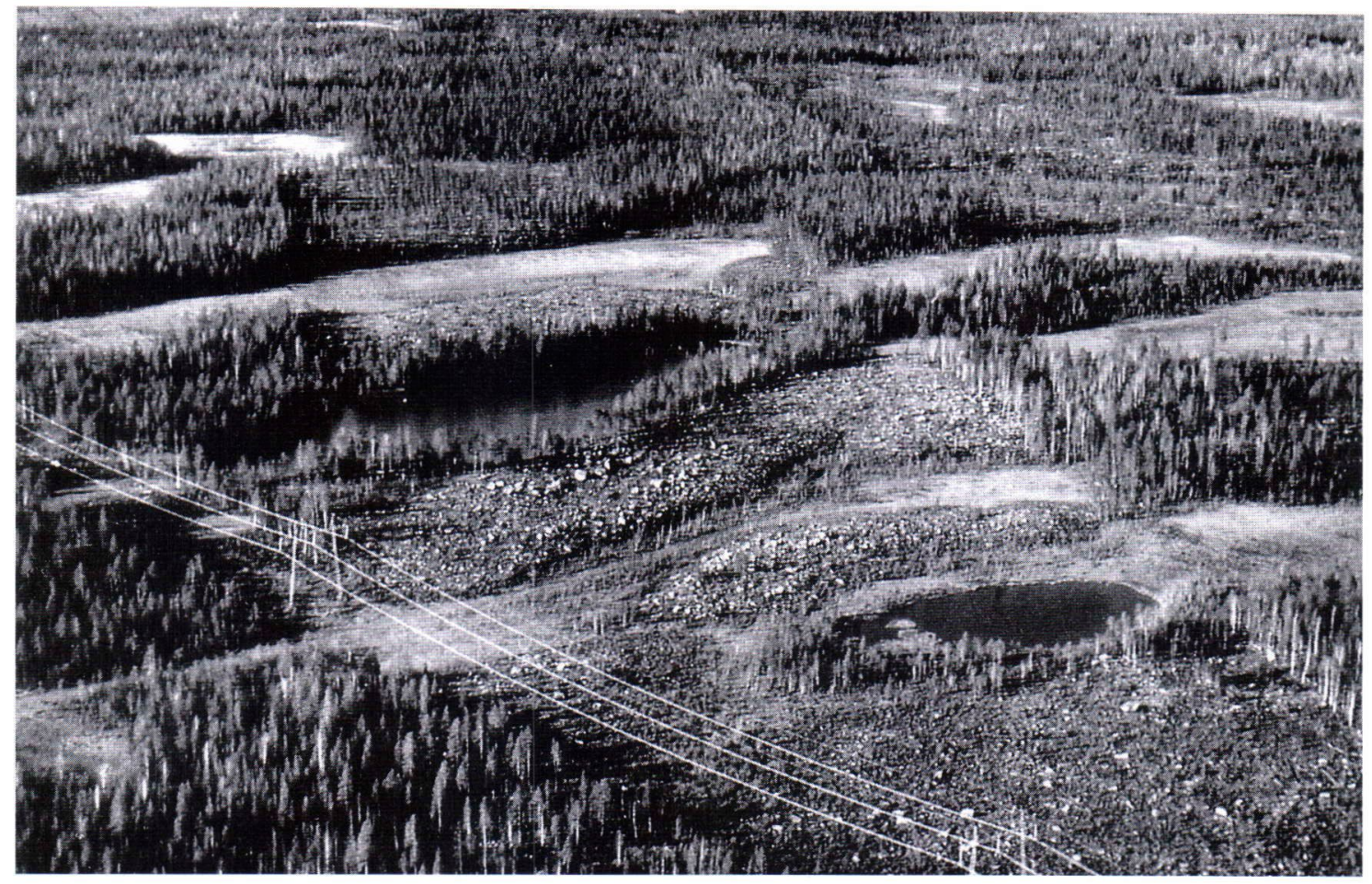

Fig. 5. An oblique aerial photograph of the Rogen moraine ridges at the western side of Petäjäskoski. Ridges are characteristically crescentic and covered by a bouldery surface. Ice flow has been from the upper left to lower right. Photo R. Aario.

also on the southern and eastern sides of Vammavaara hill (Fig. 12). At Petäjäskoski and in the northeastern part of the study area, one can find morphological series from Rogen moraines to drumlins, a phenomenon described frequently in the literature (cf Lundqvist 1969, 1989, 1997, Aario 1977, 1990, Hättestrand 1997). Transport distances of rock material in Rogen moraines are usually short and applicability for prospecting is therefore good (Aario \& Peuraniemi 1992).

Dead-ice hummocky moraines with kettle holes occur in some places. These moraines have been deposited as ablation till on the margin of stagnant ice together with meltwater activity, which is seen as glaciofluvial sediments and meltwater channels near the hummocky moraines. Two larger esker chains have been observed: Muurola esker in the north and a branching esker chain from Ossauskoski to the east. Giant potholes in the cordierite-antophyllite-gneiss bedrock hill occur northeast of the village of Muurola, at Hirvas. They belong to the Muurola esker chain. Because of the activity of Baltic Sea stages during the postglacial emergence due to land uplift, the surface of till has often been washed or, in low areas, covered by gravelly and sandy sediments washed down from the hill slopes.

\section{METHODS}

Glacial morphology was mapped using aerial photo interpretation and subsequent field revision. Detailed till studies in the field including tractor excavations and surface boulder counting were done in the Petäjävaara and Vammavaara case study sites. Textural and structural analyses from test pits were used to compose stratigraphical sections. 

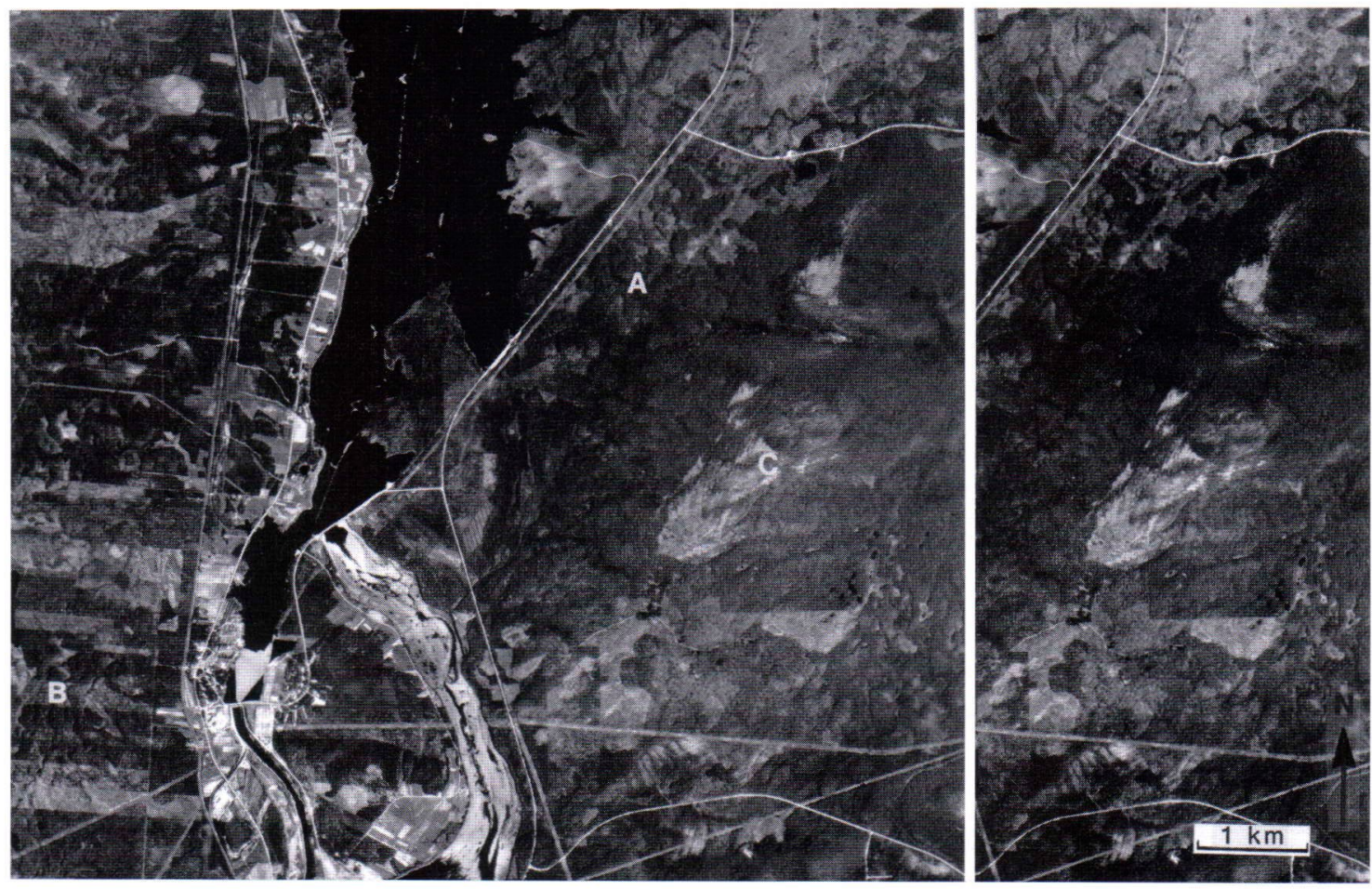

Fig. 6. Rogen moraine ridges at Petäjävaara (A) and the western side of Petäjäskoski (B) (aerial photos 7703/ 100 and 101). Petäjävaara hill with washed slopes and shore deposits is on the right margin (C). Youngest ice flow direction has been from west to east. By courtesy of Topografikunta (The Army Map Service).

Surface boulder counting has been used to estimate the glacial transport distances and to supplement bedrock data because the outcrops are few.

Samples have been taken from test pits for grain size, pebble lithology, chemical and heavy mineral analyses. Grain-size analyses were done by wet-sieving and areometry. A rock type of 100 pebbles was determined. The orientation and dip of 150 or 200 pebbles were measured in till fabric analyses. Three fractions $(<0.06 \mathrm{~mm}, 0.06-$ $0.5 \mathrm{~mm}$ and $>2 \mathrm{~mm}$ ) of till were analyzed chemically (cf Gustavsson et al. 1979, Salminen 1980). The fractions were extracted by hot aqua regia and 31 elements were analyzed by inductively coupled plasma atomic emission spectrometry (ICP-AES). Gold, Pd and Te were analyzed by graphite furnace atomic absorption spectrometry (GFAAS). All analyses were made in the laboratory of the Geological Survey of Finland at Rovaniemi. Sam- ples taken earlier by percussion drilling were also used in till geochemistry. Samples for heavy mineral study (about 101 each) were panned and magnetite was removed by hand magnete. Mineralogical composition of the heavy mineral separates was determined by X-ray diffraction (XRD) and Scanning Electron Microscope (SEM).

\section{DETAILED CASE STUDIES}

\section{Petäjävaara}

The Petäjävaara site is situated between the Petäjävaara hill and the Kemijoki river (Fig. 7). The absolute height varies between $65 \mathrm{~m}$ and $140 \mathrm{~m}$ a.s.1. (top of hill is about $223 \mathrm{~m}$ a.s.1.). Overburden is thin and several bedrock outcrops occur in the northwestern and northeastern parts. Rogen moraines dominate in central parts of the area. 


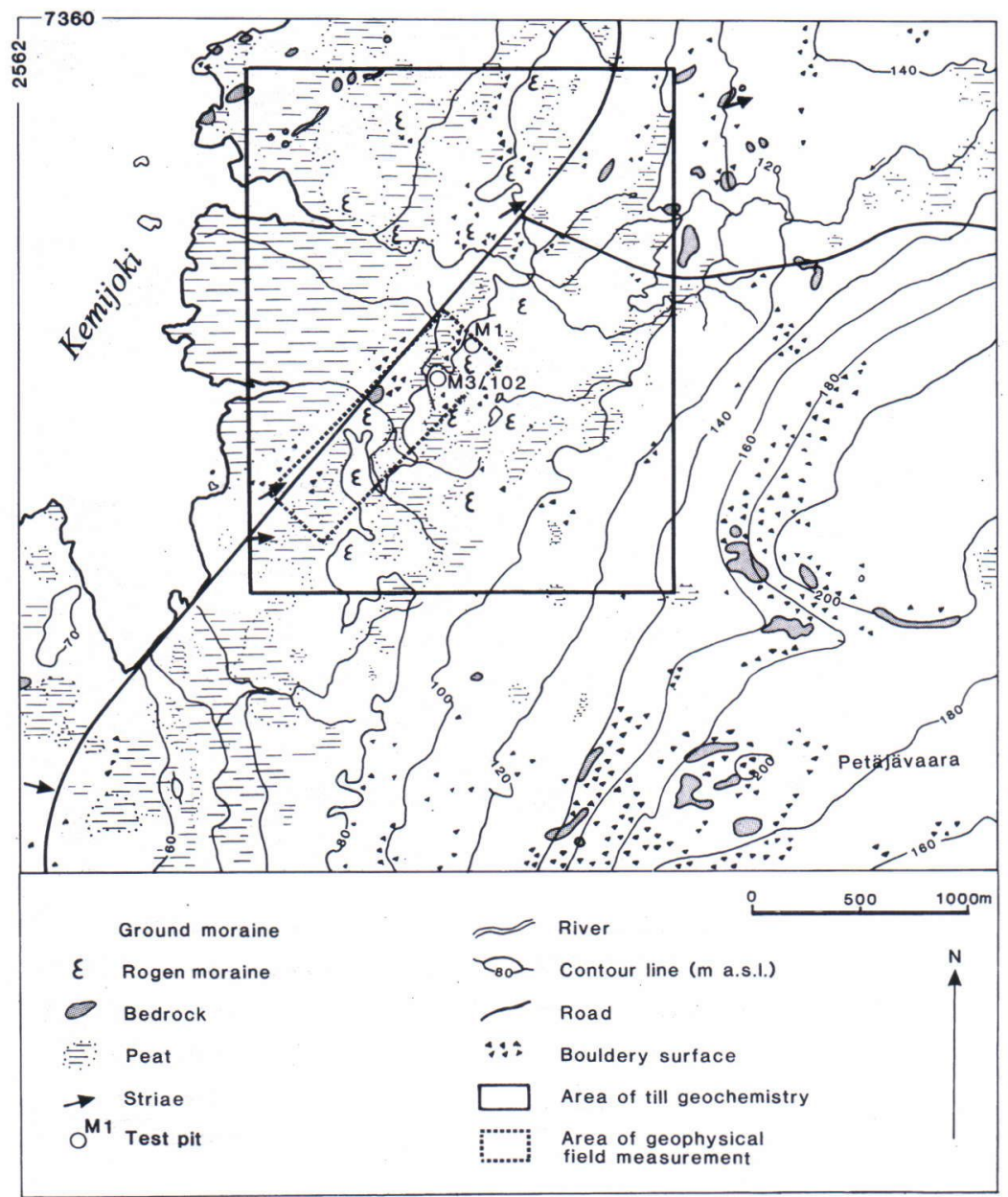

Fig. 7. Quaternary deposits and topography at Petäjävaara.

Bedrock is composed of quartzite and basic volcanic rocks (Fig. 8). Some diabase dykes are present in the southern parts of the area. Variation in the bedrock lithology is reflected in the boulder lithology on the ground surface. Two types of ore boulders have been found. Quartzite boulders are common $0.5 \mathrm{~km}$ to the NW from the test pit M1, and boulders of basic volcanic rock near the test pit M1. Both types are hydrothermally altered containing pyrite, chalcopyrite and magnetite. Boulders are quite large and angular.

A few striae observations were made at Petäjävaara. One cross striae set $\left(336^{\circ}\right.$ and 275 $280^{\circ}$ ) was found on the northern side of the case study site. The older ice flow direction is northwesterly and the younger one westerly. Four observations $\left(245^{\circ}, 245^{\circ}, 265^{\circ}, 278^{\circ}\right)$ of an age of the younger ice movement were found. A SW-NE direction is a sign of flow deflection of the glacier ice in front of the Petäjävaara hill.

\section{Till stratigraphy}

Rogen moraine ridges are composed of two till units (Fig. 9), which represent different ice flow phases. The lower unit is grey sandy till $\left(\mathrm{D}_{50}=\right.$ $0.5 \mathrm{~mm}$ ), which is mainly massive, but in places some fine-grained laminae can be found. The clay 


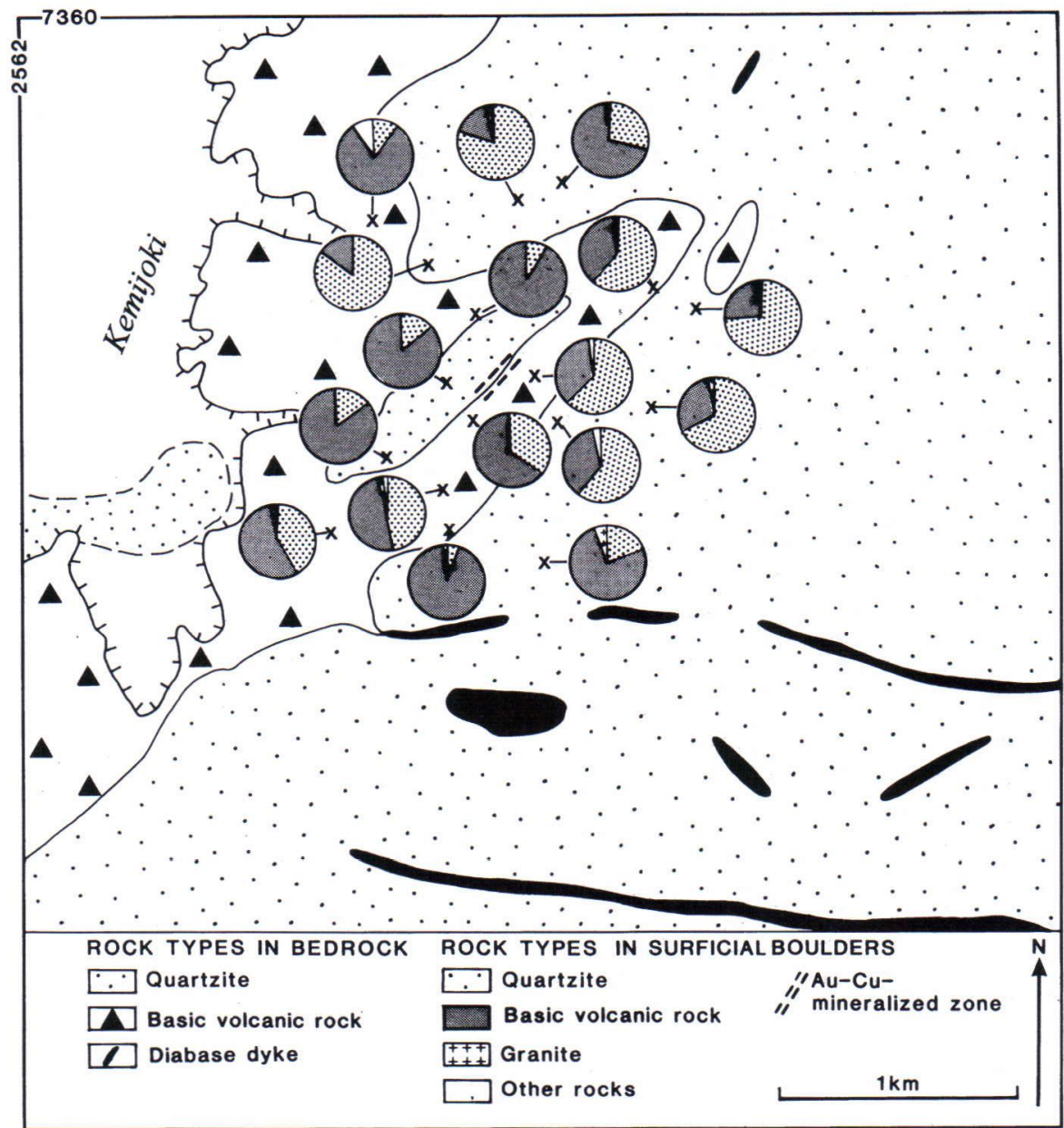

Fig. 8. Bedrock geology and surficial boulder lithology at Petäjävaara. Local ice flow direction has been from southwest to northeast because the glacier flow was deflecting around the Petäjävaara hill.

content is low. The clast lithology is: $37 \%$ quartzite, $53 \%$ basic volcanic rock, $5 \%$ granite and $5 \%$ other rock types (phyllite, vein quartz or chlorite schist). Granite clasts represent far-transported debris because their source rock is $30 \mathrm{~km} \mathrm{NW}$ in the Central Lapland Granite Complex. Clasts are usually rounded with long-axes orientation NWSE and inclination of $10-15^{\circ}$ to the southeast. A clear transverse orientation is also seen in a composite rose diagram (Fig. 9). The poor pebble orientation was possibly caused by the disturbing effect of large boulders in till during deposition. Because of its compact structure and mature texture this grey till has been interpreted to be a ba- sal till (cf Dreimanis 1989), deposited during an active ice flow from northwest.

Between the two till units one can often find a sheared zone, layers of sand and sometimes a boulder pavement.

The upper unit is sandy or gravelly $\left(D_{50}=5.25\right.$ $\mathrm{mm}$ ), brownish grey till, which is more heterogeneous than the lower one. Clay content is low (under $1 \%$ ). Deformation, fine-grained layers and sandy lenses are typical features. The amount of very angular pebbles and boulders is high. Clast lithology varies according to variations of rock types in the underlying bedrock. The content of granitic pebbles is lower as compared to the low- 


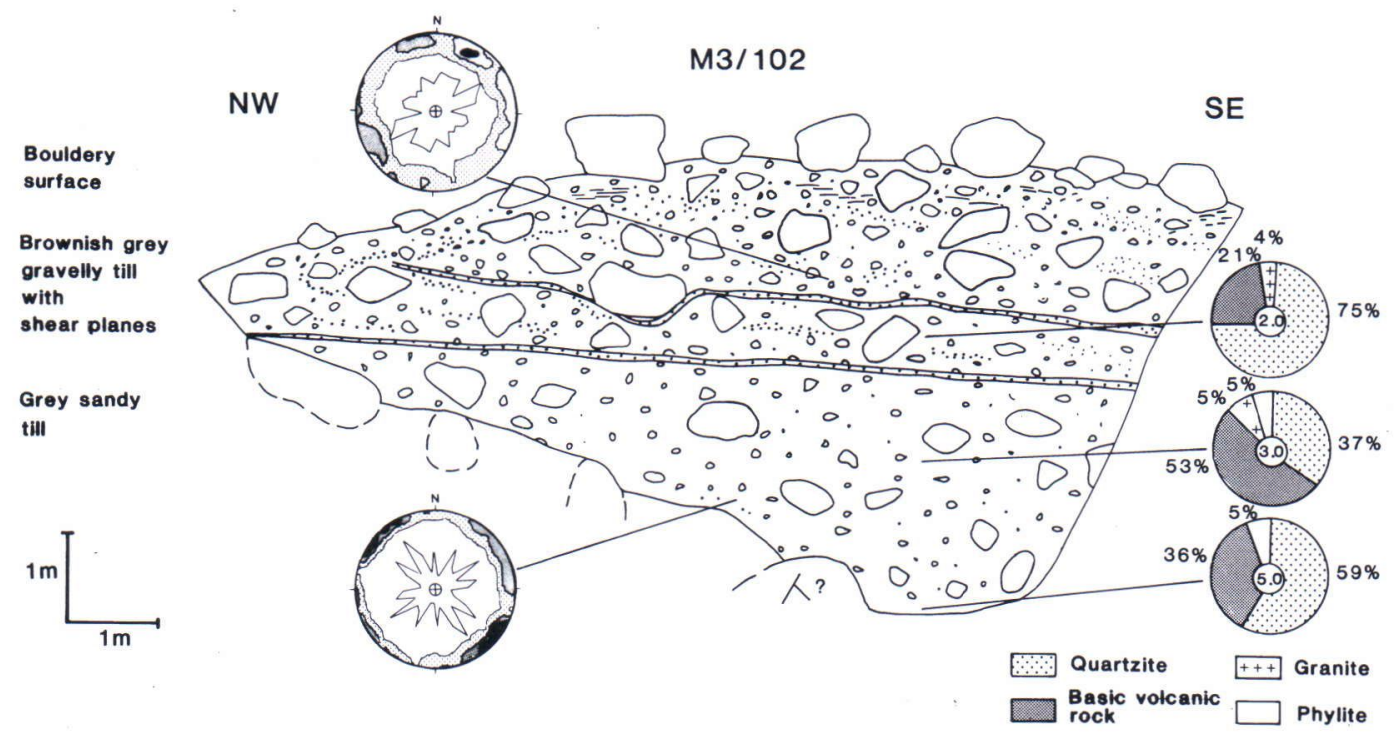

Fig. 9. Lithostratigraphy of section M3/102 at Petäjävaara.

er till unit. The presence of very easily crushable schist pebbles and pyrite crystals in till matrix are signs of the local provenance. Till fabric analyses show an orientation maximum in the direction of $240-270^{\circ}$ with low $\left(10-20^{\circ}\right)$ inclination. A general ice flow direction has been W-E. The more southwesterly direction is caused by deviating movement of the ice sheet around the Petäjävaara hill. Gravelly and sandy shore deposits cover the upper till unit in some test pits. These deposits are usually $1-1.5 \mathrm{~m}$ thick and occur at $100 \mathrm{~m}$ a.s.l.

The coarse texture, sandy lenses and finegrained sediment layers together with good till fabric are the typical features of a melt-out till (Boulton 1976, Dreimanis 1976, 1989, 1990). Steep inclination in some till fabric analyses may be caused by the deposition in subglacial or marginal conditions during flow processes. Also meltwater activity at the time of deposition is a noteworthy factor because a lot of fine-grained particles have been washed away from primary glacial debris.

\section{Till geochemistry}

Statistical parameters for the contents of the analyzed elements in the fine fraction of till are shown in Table 1. The distributions of $\mathrm{Au}, \mathrm{Cu}$ and $\mathrm{Te}$ are positively skewed, which can be seen in the high values of standard deviation and the coefficient of variation. Arsenic contents are low and have no correlation with $\mathrm{Au}(\mathrm{r}=0.02)$. This is significant because As is usually regarded as a good pathfinder for Au (Boyle 1979). Tellurium contents are low, too, but they correlate well with $\mathrm{Au}(\mathrm{r}=$ 0.81 ). The correlation between $\mathrm{Cu}$ and $\mathrm{Au}$ is also $\operatorname{good}(\mathrm{r}=0.70)$.

The statistical parameters for the contents of the analyzed elements in the fine fraction of till from percussion drilling are presented in Table 2. Arsenic has not been analyzed. The mean contents of metals, especially that of $\mathrm{Cu}$, are high. The standard deviation of Au contents is high and the coefficient of variation is even higher than in the test pit samples. This shows anomalous distribution and local derivation of $\mathrm{Au}$ in till. The correlation between $\mathrm{Au}$ and other metals is poor.

The areal distributions of $\mathrm{Au}, \mathrm{Cu}$ and $\mathrm{Co}$ contents are shown in Fig. 10. Both test pit and percussion drilling samples have been taken into account. Only the highest contents (one sample/pit) from the test pit samples have been included. Gold and Co have anomalous values almost in the whole test area. The high $\mathrm{Cu}$ contents are concen- 
Table 1. Statistical parameters of elements in the fine fraction of till from test pits at Petäjävaara. $x=$ arithmetic mean, $s=$ standard deviation, $m d=$ median, $c=$ coefficient of variation, min $=$ minimum and max $=$ maximum. $n=$ number of samples.

\begin{tabular}{lrrrrrrr}
\hline & $\begin{array}{c}\mathrm{Au} \\
\mathrm{ppb}\end{array}$ & $\begin{array}{c}\mathrm{As} \\
\mathrm{ppm}\end{array}$ & $\begin{array}{c}\mathrm{Co} \\
\mathrm{ppm}\end{array}$ & $\begin{array}{c}\mathrm{Cu} \\
\mathrm{ppm}\end{array}$ & $\begin{array}{c}\mathrm{Ni} \\
\mathrm{ppm}\end{array}$ & $\begin{array}{r}\mathrm{Te} \\
\mathrm{ppb}\end{array}$ & $\mathrm{n}$ \\
\hline $\mathrm{x}$ & 13 & 5 & 23 & 366 & 46 & 41 & 90 \\
$\mathrm{~S}$ & 39 & 3 & 11 & 423 & 31 & 42 & \\
$\mathrm{md}$ & 3 & 5 & 19 & 208 & 31 & 29 & \\
$\mathrm{c}$ & 2.9 & 0.6 & 0.5 & 1.2 & 0.7 & 1.0 & \\
$\min$ & $<1$ & $<3$ & 7 & 35 & 17 & 7 & \\
$\max$ & 245 & 11 & 54 & 3030 & 162 & 315 & \\
\hline
\end{tabular}

Table 2. Statistical parameters of elements in the fine fraction of till from percussion drilling at Petäjävaara. $x=$ arithmetic mean, $s=$ standard deviation, $m d=$ median, $c=$ coefficient of variation, min $=$ minimum and max $=$ maximum. $n=$ number of samples.

\begin{tabular}{lrrrrrr}
\hline & $\begin{array}{c}\mathrm{Au} \\
\mathrm{ppb}\end{array}$ & $\begin{array}{c}\mathrm{Co} \\
\mathrm{ppm}\end{array}$ & $\begin{array}{c}\mathrm{Cu} \\
\mathrm{ppm}\end{array}$ & $\begin{array}{c}\mathrm{Ni} \\
\mathrm{ppm}\end{array}$ & $\begin{array}{c}\mathrm{Te} \\
\mathrm{ppb}\end{array}$ & $\mathrm{n}$ \\
\hline $\mathrm{x}$ & 5 & 23 & 203 & 49 & 38 & 166 \\
$\mathrm{~s}$ & 32 & 15 & 198 & 88 & 67 & $63(\mathrm{Te})$ \\
$\mathrm{md}$ & 1 & 18 & 139 & 38 & 25 & \\
$\mathrm{c}$ & 6.1 & 0.7 & 1.0 & 1.8 & 1.8 & \\
$\min$ & $<1$ & 5 & 7 & 10 & $<1$ & \\
$\max$ & 417 & 88 & 1100 & 1120 & 533 & \\
\hline
\end{tabular}

trated in the central part of the area. The highest contents of all three metals follow the NE-SW oriented contact zone of quartzite and basic volcanic rock (cf Fig. 8).

In order to study the distribution of metals between different size fractions, 30 samples from seven test pits were sieved. Twenty three samples were from brownish grey till (Fig. 11) and seven from grey till. The overall figure for $\mathrm{Au}, \mathrm{Cu}$ and Te is almost the same with the highest contents in the fine fraction. The behaviour of $\mathrm{S}$ is different: the highest contents are in the sand fraction. One possible explanation is that pyrite is quite coarse-grained in the bedrock and therefore it has been enriched in the coarser fractions of the till. Gold and $\mathrm{Cu}$ have very high contents in every analyzed fraction above and/or near the mineralized zone. The test pit M1 is a very good example of that. Relatively high contents in test pit M4 are also a sign of the close relationship between the mineralized zone and the till. Some high $\mathrm{Au}$ contents in test pit M104 obviously derive from a very local, unknown source rock.

As a result of the present exploration, $\mathrm{Cu}-\mathrm{Au}$ mineralization in the shear zone was localized in the close vicinity of the ore boulders near the test pit M1 (Fig. 8). The transport distance of the boulders was only a few metres or some tens of metres at most.

\section{Vammavaara}

The Vammavaara site is located to south from the Vammavaara hill (Figs. 12 and 13). The absolute height varies between $60 \mathrm{~m}$ and $120 \mathrm{~m}$ a.s.l. (the top of the hill is about $228 \mathrm{~m}$ a.s.1.). The northern part of the area is dominated by Rogen moraine. Dead-ice hummocky moraines with kettle holes occur to the south of Suolijoki. In the southern part, till is thin and a lot of bedrock outcrops are present. No striae observations have been made at Vammavaara.

The bedrock is composed of quartzite, basic volcanic rocks, tuffite, dolomite and phyllite (Fig. 14). 

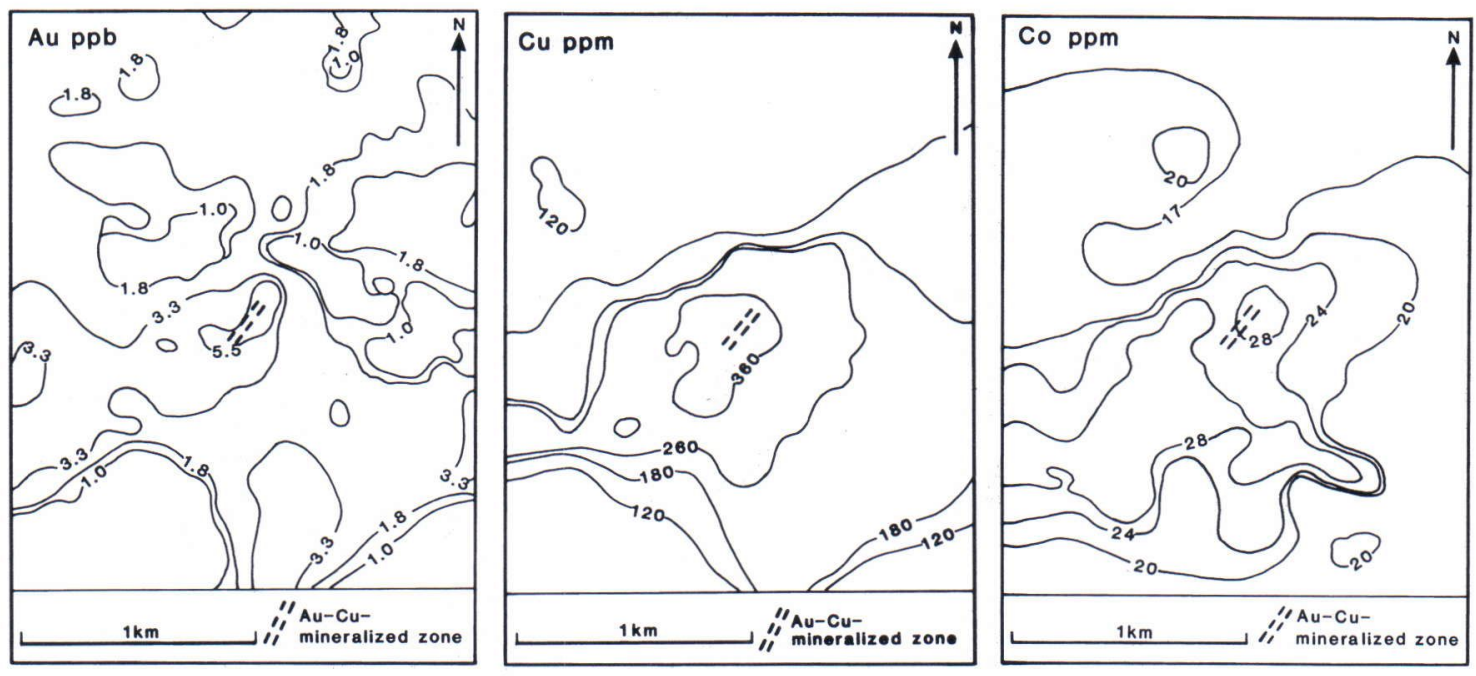

Fig. 10. Distribution of a) $\mathrm{Au}, \mathrm{b}) \mathrm{Cu}$ and c) Co in till at Petäjävaara.

The proportion of far-transported granites in the surface boulders is higher than at Petäjävaara, particularly in the western part. This reflects the relatively high amount of englacially or supraglacially transported material in the surficial till. Local derivation of boulders is clearly seen in the central and eastern part of the boulder counting area, both of which are dominated by Rogen moraine ridges. Two ore boulders of basic volcanic rock type have been found (Fig. 13 and 14).

\section{Till stratigraphy}

Three different till units representing different ice flow phases have been observed in the Rogen moraines at Vammavaara (Fig. 15). The lowermost unit is a dark, bluish grey till, which has been found as a layer in the bottom of two test pits (M21/113, M28) and as lenses in upper till in some test pits. The till is fine-grained $\left(D_{50}=0.2\right.$ $\mathrm{mm}$ ) and its clay content is relatively high (7\%). Only one fabric analysis with NW-SE orientation and low inclination of pebbles $\left(5-10^{\circ}\right)$ was done. Pebbles are well-abraded and rounded. Pebble lithology is as follows: $40 \%$ quartzite, $20 \%$ basic volcanic rock, $20 \%$ granite and $20 \%$ other rock types (phyllite, dolomite and vein quartz). The dark till has been preserved in low-lying areas on proximal sides of the hills. Because of the high clay content, the till has probably been deposited as the first till bed after the Eemian interglacial period during Early Weichselian (cf Rainio \& Lahermo 1976, 1984, Hirvas 1991, Lintinen 1995) and so it includes material from the old weathering crust and pre-existing fine-grained sediments. The very compact structure might be due to the clayey matrix and the high pressure of the ice sheet during Middle Weichselian glaciation.

A two metres thick unit consisting of layers of sorted sand and gravel or stony flow sediments occurs above the dark till in the section of M28. The test pit is situated on the western slope of the Vammavaara hill. Clasts of the unit seem to be very local: almost $75 \%$ are quartzites derived from the underlying bedrock. The unit could have been deposited in certain subglacial conditions, where pressure melting under the ice has produced a lot of meltwater. The second till unit occurs directly on the dark till in test pit M21/113.

The second unit is grey sandy till $\left(D_{50}=0.4 \mathrm{~mm}\right)$, massive in its structure. Sand lenses and laminae of fine-grained sorted sediments occur. Its clay content is low (about $1 \%$ ). The clast lithology is: $30 \%$ quartzite, $40 \%$ basic volcanic rock, $15 \%$ granite and $15 \%$ other rock types (phyllite, dolomite, mica schist or vein quartz). The pebbles are rounded and 

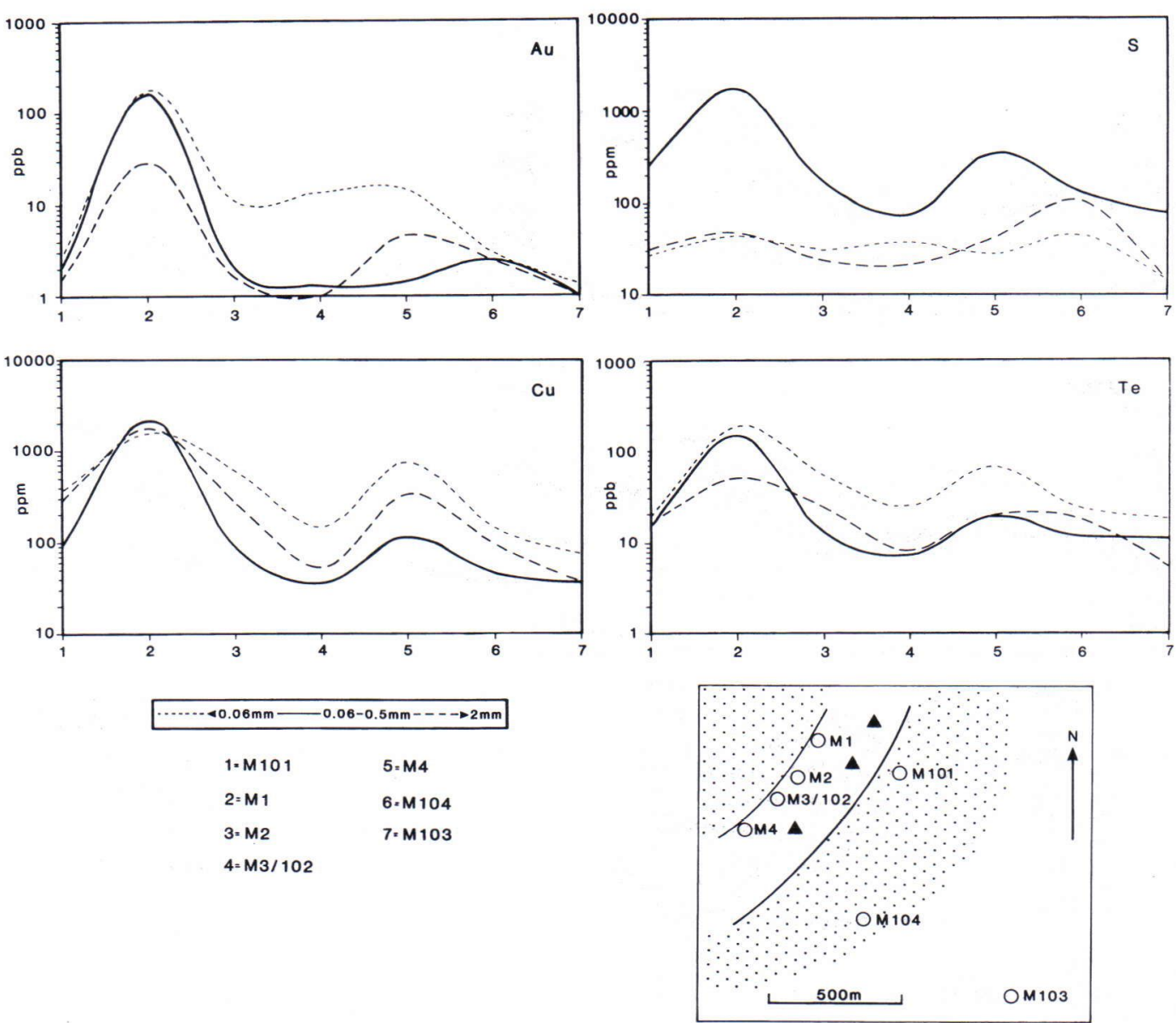

Fig. 11. Gold, $\mathrm{Cu}, \mathrm{S}$ and Te contents in three till fractions of brownish grey till at Petäjävaara. Total number of samples is 23 and arithmetic means have been used. Bedrock geology and location of test pits are shown in the map (symbols as in Fig. 8).

the inclination of their long axes is about $10-20^{\circ}$ to variable directions. Pebble orientation is mainly $\mathrm{W}$ E. Strong transverse orientation is also present in places. The compact structure with a minor stratified component suggests that the till has been deposited as lodgement till in subglacial conditions during an active ice flow from the west.

Sorted and sheared sandy or silty layers, some tens of centimetres thick, are observed above the grey till. There is also one observation of $60 \mathrm{~cm}$ thick gravelly flow sediment in the section of test pit M27 under a $15-20 \mathrm{~cm}$ thick silty layer. A gravelly $\left(D_{50}=30 \mathrm{~mm}\right)$ and dark grey diamict unit, one metre thick, occurs in two test pits (pit M33 shown in Fig. 16). It is rich in very angular boulders and pebbles (composed nearly $100 \%$ of basic volcanic rocks). It is supposed to be a slice of deformed weathering crust with quarried fresh boulders carried two hundred metres along the ice bottom. There are usually no interlayers between the lower grey and the upper till beds.

The upper till unit is variable in its characteristics in the Rogen moraine ridges. It is divided into western and eastern types. On the western part this unit is composed of sandy or gravelly brownish grey till, which is more heterogeneous and coarse $\left(D_{50}=3.2 \mathrm{~mm}\right)$ than the lower tills. The clay content is very low. The mean thickness of 

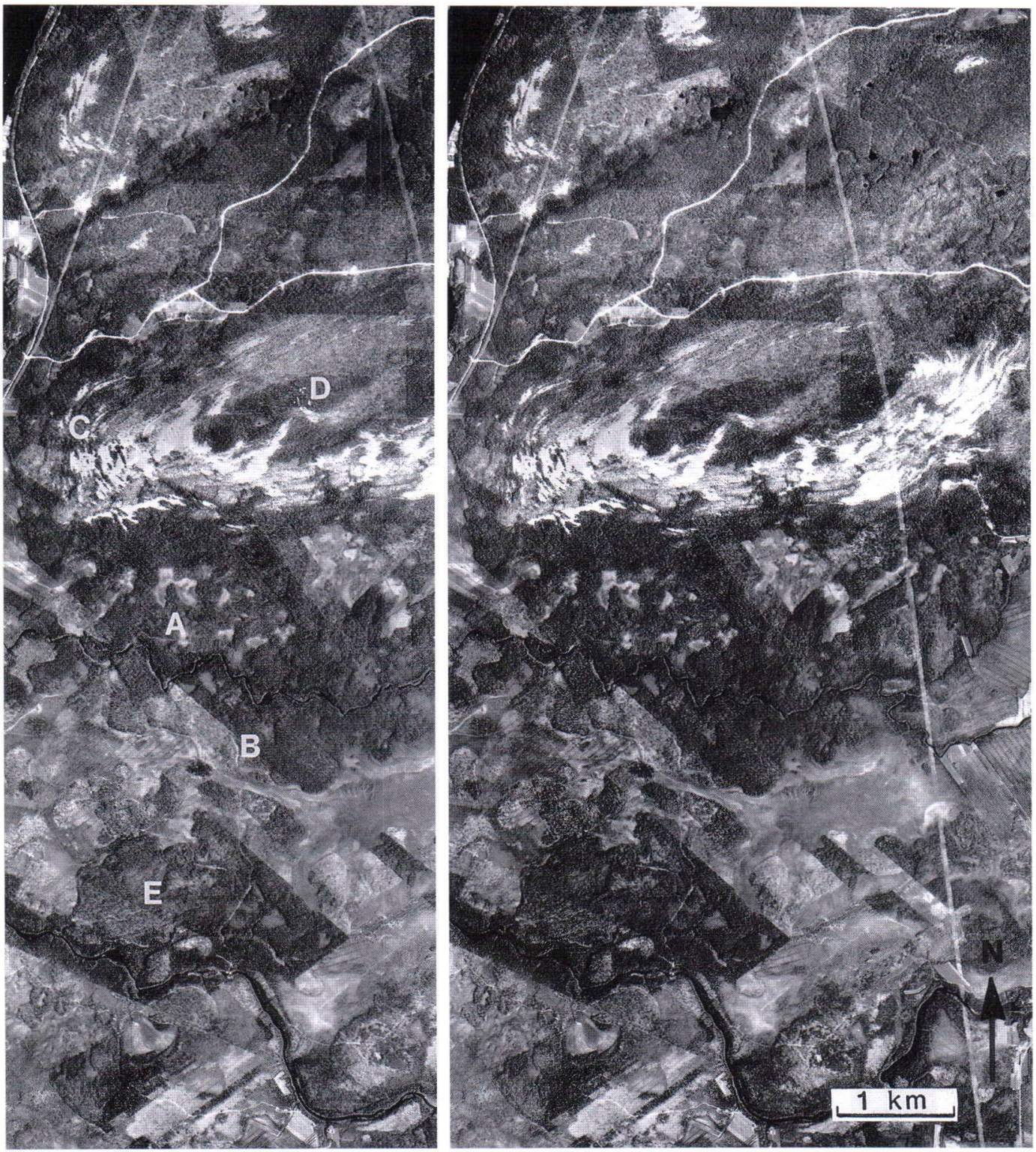

Fig. 12. Rogen moraine ridges (A), dead ice hummocks (B) and beach gravels of Ancylus Ice Lake (C) at Vammavaara (aerial photos $7703 / 15$ and 16). Vammavaara hill in the north has a supra-aquatic top (D) and in the southern parts of the figure there occurs cover moraine with plenty of outcrops $(E)$. Youngest ice flow direction has been from west to east. By courtesy of Topografikunta (The Army Map Service).

that unit is about $2.6 \mathrm{~m}$. Sandy or silty layers and lenses with deformation structures are the main features. The till contains a lot of angular pebbles and boulders whose lithological composition varies with the underlying bedrock. The amount of granite pebbles is low. Till fabric analyses show an orientation maximum in the direction $240-270^{\circ}$ with inclinations $10-20^{\circ}$. The structures indicate that the till in the western parts has been deposited as a melt-out till.

In the eastern parts of the Rogen moraine area, the mean thickness of the sandy $\left(D_{50}=0.5 \mathrm{~mm}\right)$ 


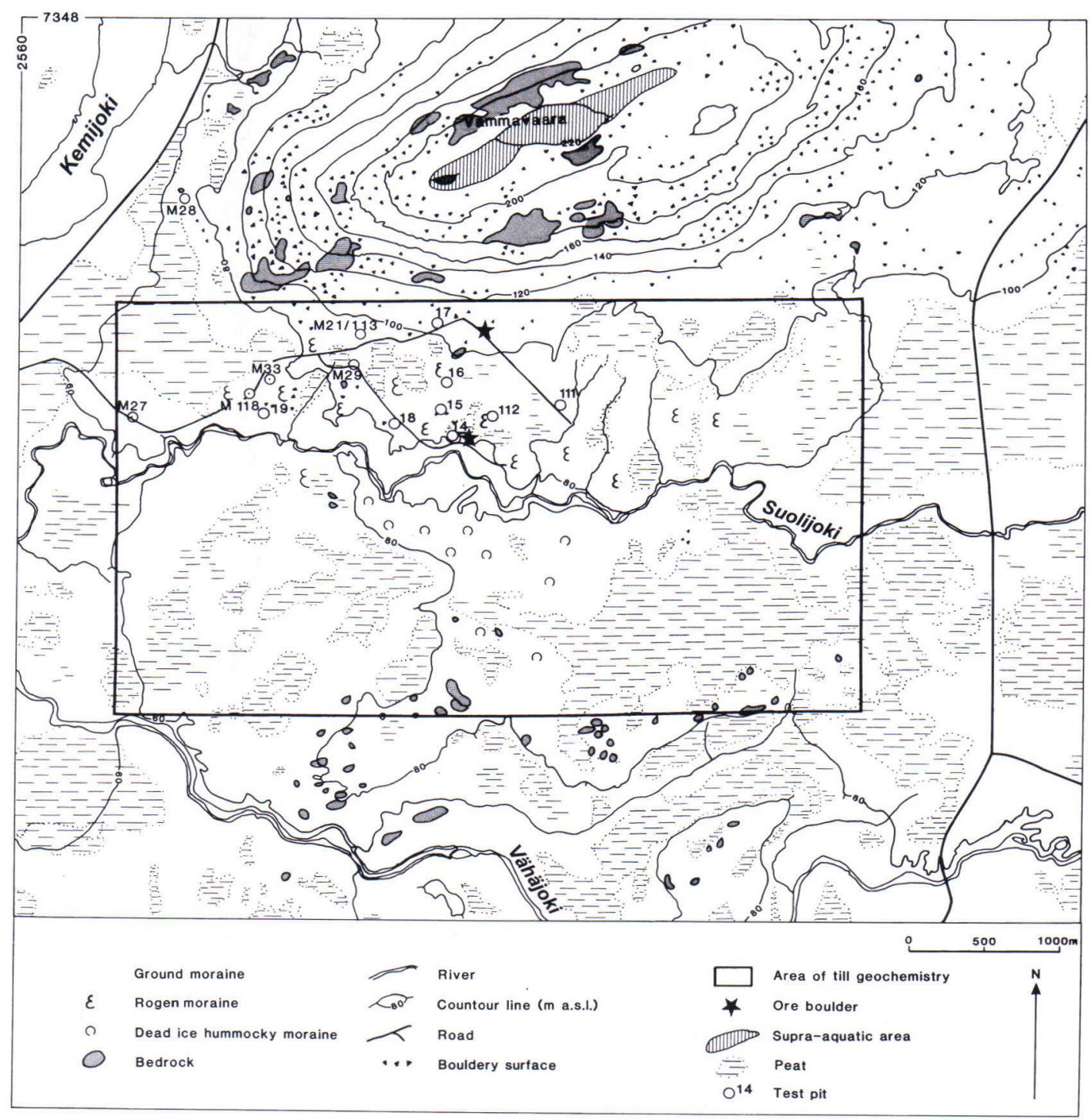

Fig. 13. Quaternary deposits and topography of Vammavaara.

till bed is $4.5 \mathrm{~m}$. The amount of boulders is lower than in the western area and a lot of sandy-rich layers and lenses have been found. These properties refer to high meltwater activity during deposition and are typical features of melt-out till. Pebbles are usually more rounded and far-travelled than in the west. Steep inclination and poor orientation of the pebbles might also be a sign of secondary flow processes during deposition.
The upper till is covered by a one metre thick silty, laminated (varved) and dropstone-rich sediment in some western test pits. It is interpreted to be a glaciolacustrine deposit. These sediments have been deposited obviously in quite a deep water, while floating icebergs have been present. At a later stage, when the water depth decreased, the upper parts of morainic ridges have been washed and covered by sandy and gravelly shore deposits. 


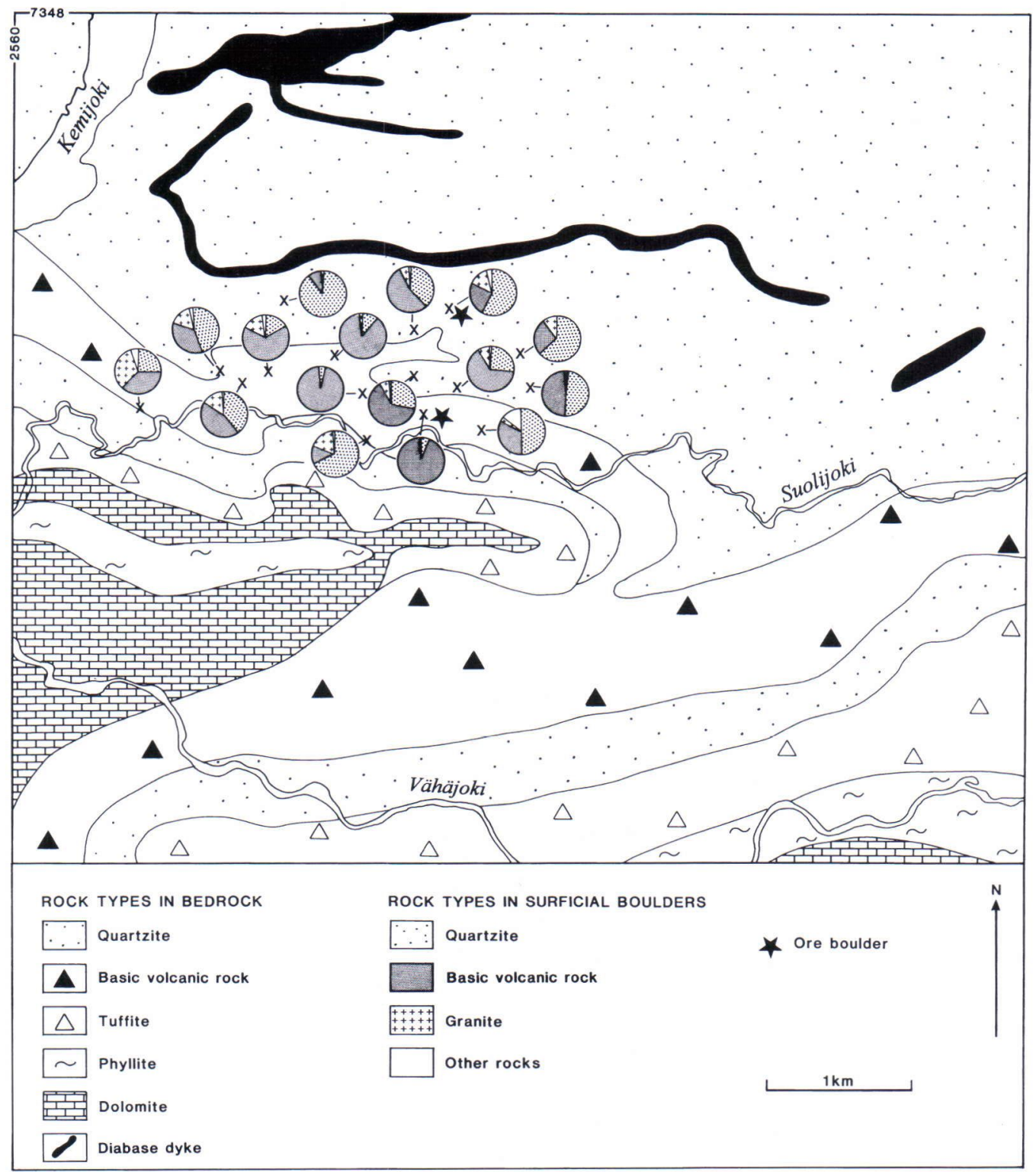

Fig. 14. Bedrock geology and the surficial boulder lithology of Vammavaara. Youngest ice flow direction has been from west to east. Sites of the two ore boulders are also marked.

\section{Till geochemistry}

Metal contents in the fine fraction of till are lower at Vammavaara as compared to those at Petäjävaara (Table 3). Copper shows anomalous distribution, but $\mathrm{Au}$ contents are only a little higher than normal in Finnish till (cf Koljonen
1992). Arsenic and Co contents are at the same level as at Petäjävaara.

The statistical parameters for the contents of the analyzed metals in the fine fraction of till of percussion drilling are presented in Table 4. Gold, Ni and Te contents are higher than in the test pit samples. Gold has a very high value of coefficient of 


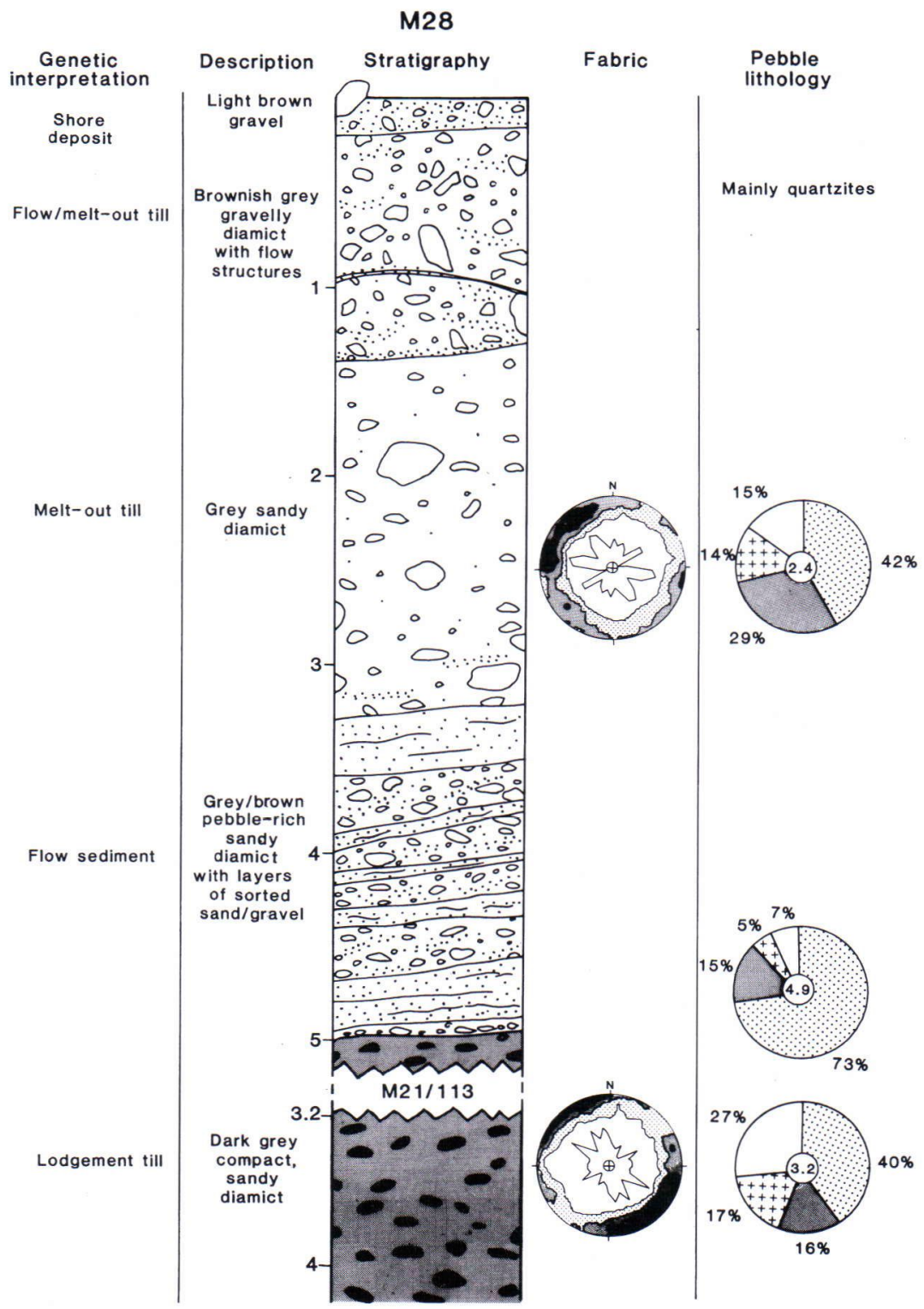

Fig. 15. Lithostratigraphy of section M28 and the bottom part of section M21/113 at Vammavaara. Pebble lithology: symbols as in Fig. 14.

variation. The correlation between different metals is poor.

The areal distributions of $\mathrm{Au}, \mathrm{Cu}$ and $\mathrm{Co}$ contents are shown in Fig. 17. The highest contents are concentrated to the northwestern and central parts associated with the occurrence of basic volcanic rock and its contact with quartzite.
Three fractions of the 45 till samples from nine test pits have been sieved from the brownish grey till unit. Gold, $\mathrm{Cu}, \mathrm{S}$ and Te contents in the different size fractions are shown in Fig. 18. In test pits M14 and M33 Au and Cu contents are clearly anomalous. Sulphur contents in the $0.06-0.5 \mathrm{~mm}$ fraction are almost tenfold compared with other 


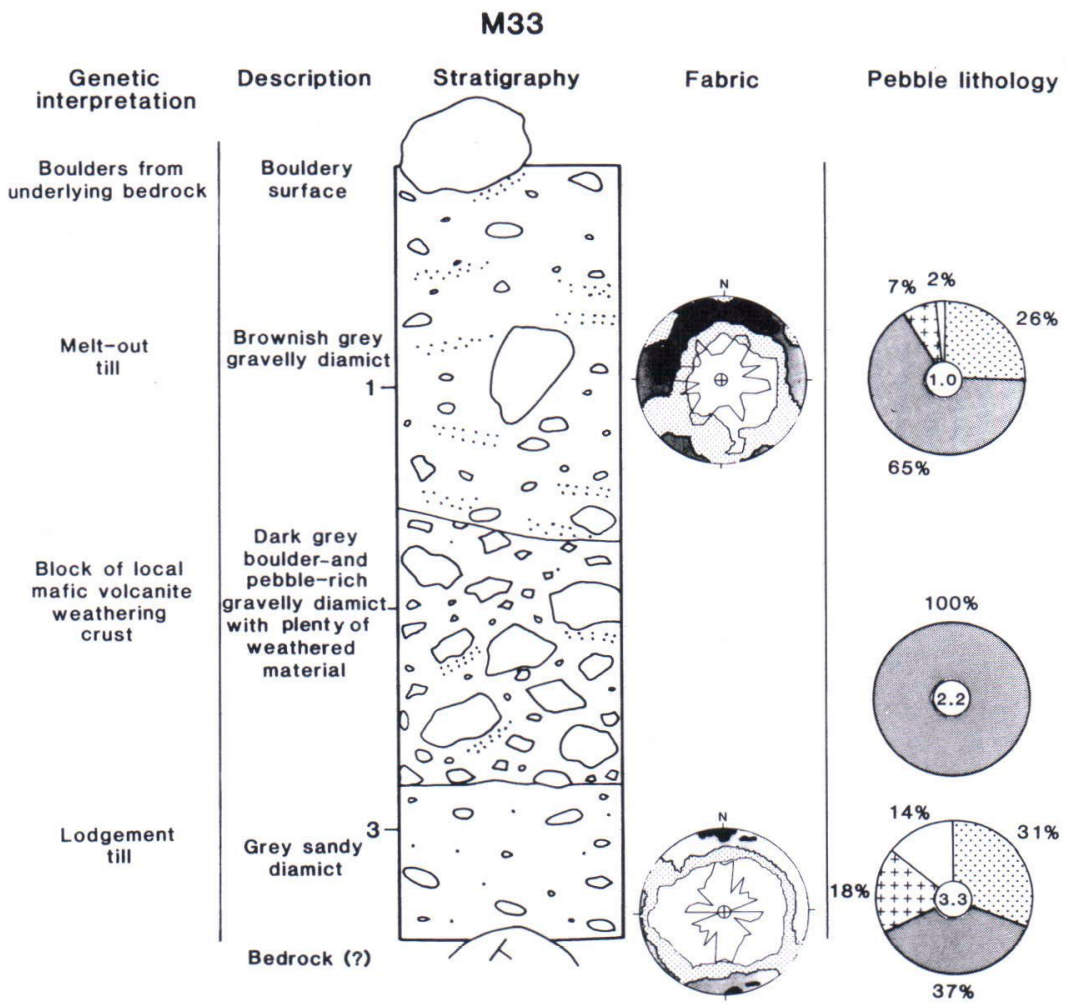

Fig. 16. Lithostratigraphy of section M33 at Vammavaara.

fractions. This feature may be explained with the same reason as at Petäjävaara, because $S$ occurs as sulphide grains in the $0.06-0.5 \mathrm{~mm}$ fraction.

\section{HEAVY MINERAL GEOCHEMISTRY}

No Au grains have been found in the heavy mineral separates, although some high Au contents in the separates both at Petäjävaara (16.9, 15.0 and 12.5 ppm) and Vammavaara (17.8, 8.3 and 2.6 ppm) have been analyzed. The reason may be the very small grain size of Au particles and also the nugget effect. Polished thin sections of ore boulder samples from Vammavaara show that the size of $\mathrm{Au}$ grains is some microns only. Statistical parameters of the analyzed metals of the heavy mineral samples are shown in Table 5. Both $\mathrm{Au}$ and $\mathrm{Cu}$ show highly skewed distribution. Samples from Petäjävaara have higher contents of $\mathrm{Au}$ and $\mathrm{Cu}$ than those from Vam- mavaara. Instead As and Co contents are at normal levels. A remarkable feature is the presence of wellpreserved sulphide minerals (Fig. 19), which could suggest that Au might occur as inclusions in chalcopyrite and pyrite grains (cf Nikkarinen 1991). However, the results show that under favourable circumstances heavy mineral geochemistry of till is also a suitable prospecting method in searching for sulphide ores as Peuraniemi has suggested earlier (1990, 1991).

\section{CONCLUSIONS}

Rogen moraine is the most prominent glacial landform type in the study area. In places it has transitional forms with drumlins. Large areas are also covered by ground and cover moraines. Proglacial Ancylus Ice Lake and the subsequent Litorina Sea have also modified the surface morphology. 
Table 3. Statistical parameters of elements in the fine fraction of till from test pits at Vammavaara. $x=$ arithmetic mean, $s=$ standard deviation, $m d=$ median, $c=$ coefficient of variation, min $=$ minimum and $\max =$ maximum. $n=$ number of samples.

\begin{tabular}{lrrrrrrr}
\hline & $\begin{array}{c}\mathrm{Au} \\
\mathrm{ppb}\end{array}$ & $\begin{array}{c}\mathrm{As} \\
\mathrm{ppm}\end{array}$ & $\begin{array}{c}\mathrm{Co} \\
\mathrm{ppm}\end{array}$ & $\begin{array}{c}\mathrm{Cu} \\
\mathrm{ppm}\end{array}$ & $\begin{array}{c}\mathrm{Ni} \\
\mathrm{ppm}\end{array}$ & $\begin{array}{r}\mathrm{Te} \\
\mathrm{ppb}\end{array}$ & $\mathrm{n}$ \\
\hline $\mathrm{x}$ & 3 & 4 & 19 & 107 & 25 & 16 & 178 \\
$\mathrm{~S}$ & 6 & 2 & 16 & 114 & 9 & 12 & 150 (As) \\
$\mathrm{md}$ & 1 & 4 & 14 & 60 & 23 & 13 & \\
$\mathrm{c}$ & 2.2 & 0.6 & 0.8 & 1.1 & 0.4 & 0.7 & \\
$\min$ & $<1$ & $<3$ & 7 & 16 & 12 & 5 & \\
$\max$ & 57 & 13 & 140 & 923 & 74 & 73 & \\
\hline
\end{tabular}

Table 4. Statistical parameters of elements in the fine fraction of till from percussion drilling at Vammavaara. $x$ $=$ arithmetic mean, $s=$ standard deviation, $m d=$ median, $c=$ coefficient of variation, $\min =$ minimum and max $=$ maximum. $n=$ number of samples.

\begin{tabular}{lrrrrrl}
\hline & $\begin{array}{c}\mathrm{Au} \\
\mathrm{ppb}\end{array}$ & $\begin{array}{c}\mathrm{Co} \\
\mathrm{ppm}\end{array}$ & $\begin{array}{c}\mathrm{Cu} \\
\mathrm{ppm}\end{array}$ & $\begin{array}{c}\mathrm{Ni} \\
\mathrm{ppm}\end{array}$ & $\begin{array}{c}\mathrm{Te} \\
\mathrm{ppb}\end{array}$ & $\mathrm{n}$ \\
\hline $\mathrm{x}$ & 4 & 15 & 58 & 30 & 19 & 236 \\
$\mathrm{~S}$ & 23 & 8 & 52 & 13 & 18 & \\
$\mathrm{md}$ & 1 & 12 & 39 & 26 & 15 & \\
$\mathrm{c}$ & 5.8 & 0.5 & 0.9 & 0.4 & 0.9 & \\
$\min$ & $<1$ & 6 & 3 & 8 & 2 & \\
$\max$ & 322 & 71 & 331 & 95 & 170 & \\
\hline
\end{tabular}
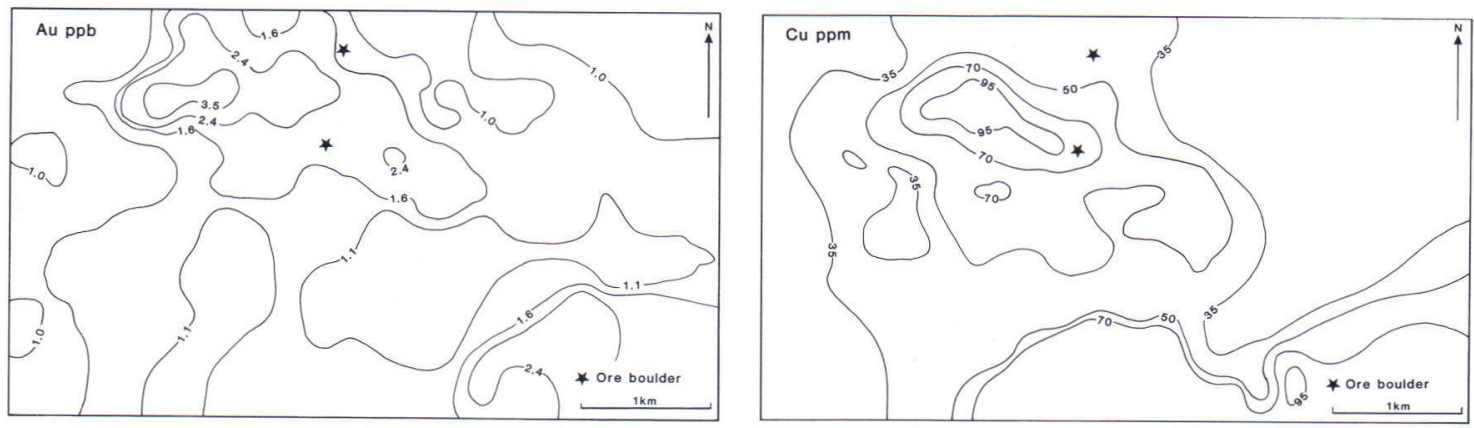

Fig. 17. Distribution of a) $\mathrm{Au}, \mathrm{b}) \mathrm{Cu}$ and c) Co in till at Vammavaara.

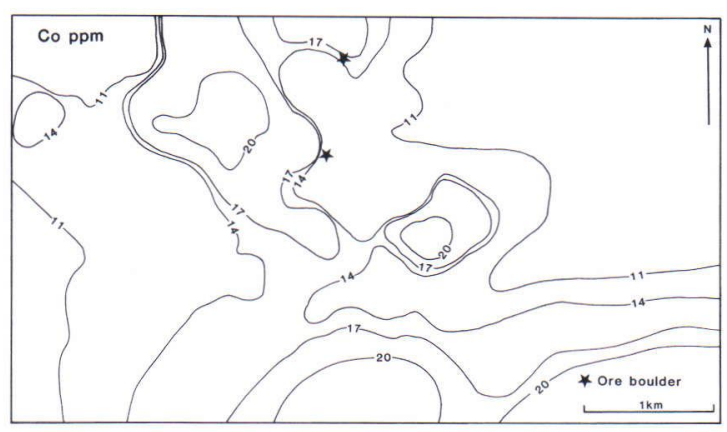



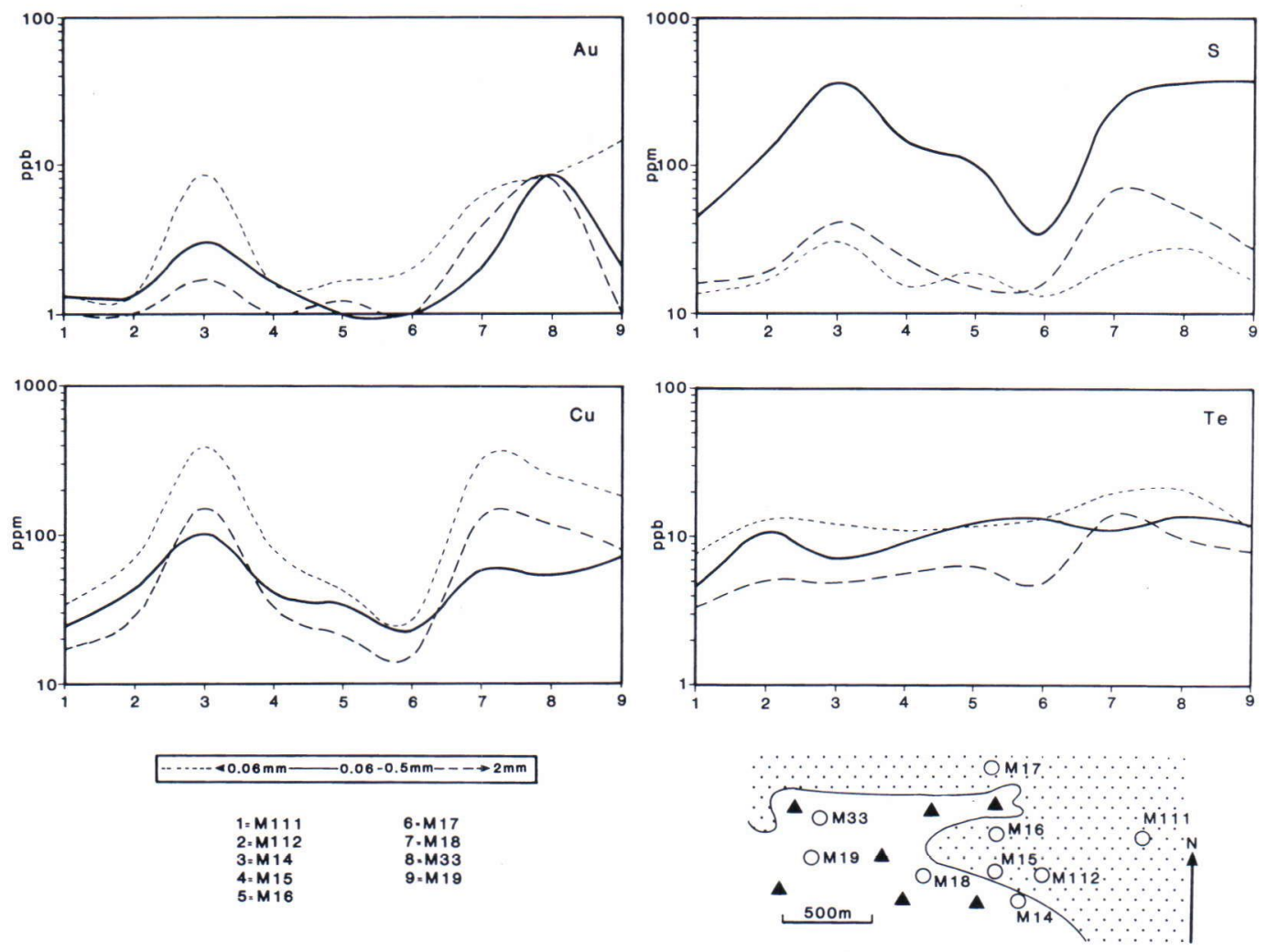

Fig. 18. Gold, Cu, S and Te contents in three till fractions of brownish grey till at Vammavaara. Total number of samples is 23 and arithmetic means have been used. Bedrock geology and location of test pits are shown in the map (symbols as in Fig. 14).

Three till beds with sorted interlayers have been found in the area. The lowest till bed, found at Vammavaara only, has a dark bluish grey colour, is rich in clay and silt and has a homogeneous and compact structure. That till bed with its NW-SE clast orientation has been interpreted as being formed in subglacial conditions during very early stages of Weichselian glaciation after Eemian interglacial, as proposed by Rainio and Lahermo (1976, 1984). The dark grey till is correlated with till bed III described by Hirvas et al. (1977) and Hirvas (1991). The second till bed with sandy matrix, far-transported pebbles, some sandy laminae and grey colour deposited as a melt-out till in subglacial conditions during the ice flow stage from west or northwest. The third and the uppermost till bed, composed of brownish grey sandy or gravelly till containing a lot of very local boul- ders and pebbles, deposited as a melt-out or flow till as one can conclude from the structures like sorted sandy and silty lenses, fine-grained sediment layers and deformation structures. The main ice flow direction was toward the east, but local variations do occur due to the diverging ice movement around the highest hills. The upper till unit exists on both Petäjävaara and Vammavaara case study sites. Between different till beds, in particular at Vammavaara, there occur gravelly and/or sandy sediments as stratified interlayers. The till beds discussed here correlate with till beds II and I in Lapland (Hirvas 1991) and they also represent the two characteristic till facies of Rogen moraines as described by Aario (1990) at Portimojärvi, Ranua.

The results of till geochemistry show that there are anomalous contents of $\mathrm{Au}$ and $\mathrm{Cu}$ in all till 
Table 5. Statistical parameters of elements in the heavy mineral separates at Petäjävaara and Vammavaara. $x=$ arithmetic mean, $s=$ standard deviation, $m d=$ median, $c=$ coefficient of variation, min $=$ minimum and max $=$ maximum. $n=$ number of samples.

\begin{tabular}{lrccccccc}
\hline & \multicolumn{3}{c}{ Petäjävaara $\mathrm{n}=19$} & \multicolumn{3}{c}{ Vammavaara $\mathrm{n}=33$} \\
\hline & $\begin{array}{c}\mathrm{Au} \\
\mathrm{ppm}\end{array}$ & $\begin{array}{c}\mathrm{As} \\
\mathrm{ppm}\end{array}$ & $\begin{array}{c}\mathrm{Co} \\
\mathrm{ppm}\end{array}$ & $\begin{array}{c}\mathrm{Cu} \\
\mathrm{ppm}\end{array}$ & $\begin{array}{c}\mathrm{Au} \\
\mathrm{ppm}\end{array}$ & $\begin{array}{c}\text { As } \\
\mathrm{ppm}\end{array}$ & $\begin{array}{c}\mathrm{Co} \\
\mathrm{ppm}\end{array}$ & $\begin{array}{c}\mathrm{Cu} \\
\mathrm{ppm}\end{array}$ \\
\hline $\mathrm{x}$ & 4 & 33 & 48 & 209 & 2 & 35 & 55 & 47 \\
$\mathrm{~s}$ & 6 & 7 & 14 & 602 & 4 & 11 & 42 & 42 \\
$\mathrm{md}$ & 1 & 35 & 46 & 69 & 1 & 33 & 38 & 26 \\
$\mathrm{c}$ & 1.6 & 0.2 & 0.3 & 2.9 & 2.1 & 0.3 & 0.8 & 0.9 \\
min & 0.01 & 21 & 31 & 33 & $<0.01$ & 21 & 21 & 10 \\
max & 17 & 40 & 89 & 2690 & 18 & 75 & 169 & 179 \\
\hline
\end{tabular}

fractions in both case study sites, Petäjävaara and Vammavaara. Metal contents in coarse till fractions are highest just over the mineralized zone and concentrations decrease rapidly as the transport distance increases. The most effective pathfinder elements for $\mathrm{Au}$, besides $\mathrm{Au}$ itself, are $\mathrm{Cu}$, Te and Co having good or moderate correlations with $\mathrm{Au}$. Arsenic with very low contents does not show any relation with Au.
As a result of detailed exploration studies, the $\mathrm{Cu}-\mathrm{Au}$ mineralized zone in the contact of basic volcanic rock and quartzite was discovered at Petäjävaara. The transport distance of surficial boulders is usually only from some metres to some tens of metres. Metal contents of till at Vammavaara are lower as compared to those at Petäjävaara. Surficial boulders are mostly of local origin and transport distances are short. The

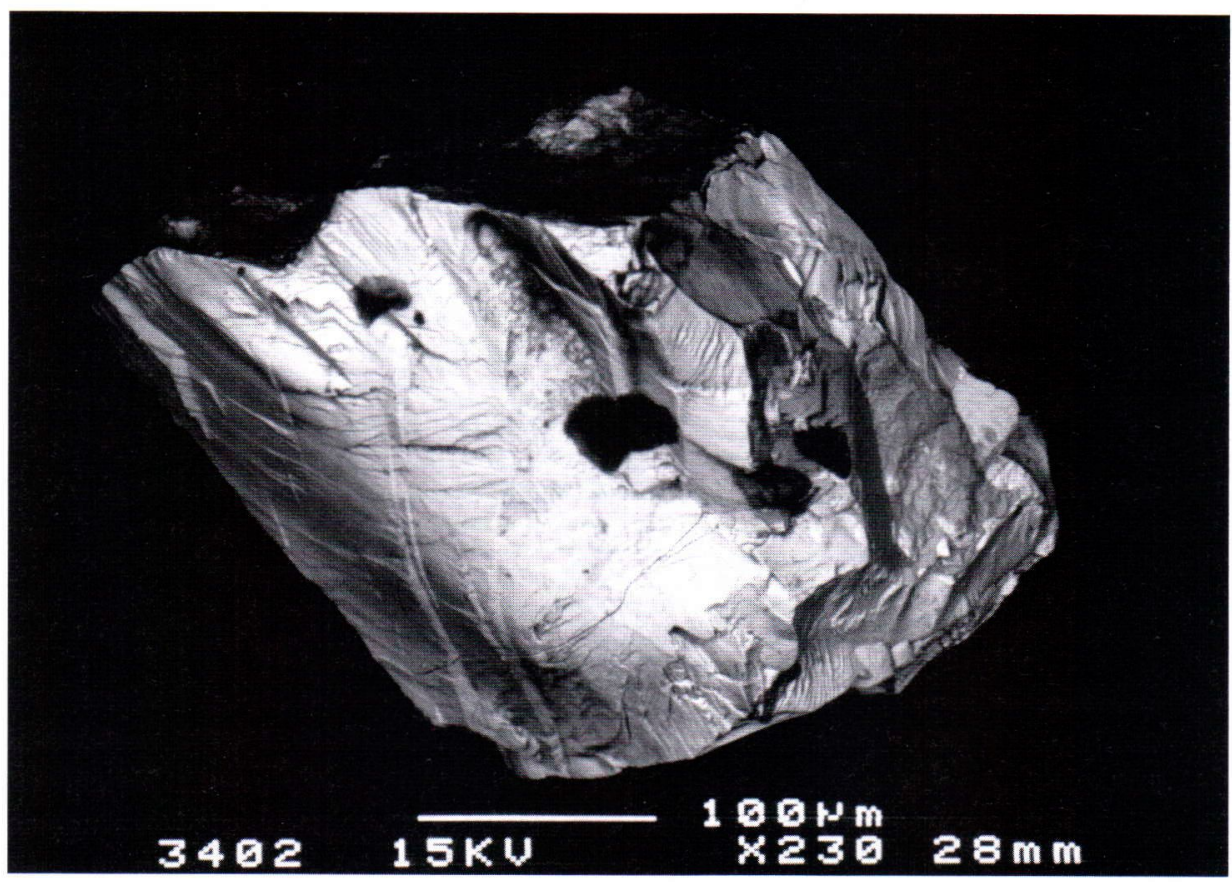

Fig. 19. A well-preserved chalcopyrite grain from till in test pit M1 at Petäjävaara. Secondary electron image by SEM. 
amount of far-transported granites is remarkable in the western part of Vammavaara and it reflects englacial or supraglacial transportation of the material in the surficial till in those areas. This leads to the conclusion that the origin of the two ore boulders could be on the western side of the studied site. However, the $\mathrm{Au}$ and $\mathrm{Cu}$ contents are anomalous in the middle of the site, so it is still possible that the source rock of the ore boulders is beyond the area studied.

ACKNOWLEDGEMENTS: Financial aid for this study has been given by the Foundation for Research of Natural Resources in Finland, University of Oulu and Geological Survey of Finland. Many workers from the staff of the Geological Survey of Finland, Regional Office in Rovaniemi have participated in the field work. Mr. Seppo Rossi acted as a co-worker during the research. Mrs. Kristiina Karjalainen draw maps and diagrams. Mr. Gordon Roberts checked the English of the manuscript. We express our sincere gratitude to all these persons and institutions.

\section{REFERENCES}

Aario, R. 1977. Classification and terminology of morainic landforms in Finland. Boreas 6, 87-100.

Aario, R. 1990. Morainic landforms in Northern Finland. In: Aario, R. (ed.) Glacial heritage of Northern Finland; an excursion guide. Nordia tiedonantoja, Sarja A: 1, 13-27.

Aario, R. \& Peuraniemi, V. 1992. Glacial dispersal of till constituents in morainic landforms of different types. Geomorphology 6, 9-25.

Aario, R., Peuraniemi, V. \& Sarala, P. 1996. Exploration problems in glacial landforms of different types; studies in southern Finnish Lapland. Short Papers and Abstracts for the Jubilee Meeting, Geologiska Föreningens i Stockholm Förhandlingar 118, Jubilee Issue, A104.

Aario, R., Peuraniemi, V. \& Sarala, P. 1997. The Sihtuuna moraine at Tervola, southern Lapland. In: Piotrowski, J.A. (ed.) Subglacial environments. Sedimentary Geology $111,135-145$.

Äyräs, M. 1991. Geochemical gold prospecting at Vinsanmaa, northern Finland. Journal of Geochemical Exploration 39 , 379-386.

Bloom, L.B. \& Steel, K.G. 1989. Gold in till: preliminary results from the Matheson area, Ontario. In: DiLabio, R.N.W. \& Coker, W.B. (eds.) Drift Prospecting. Geological Survey of Canada, Paper 89-20, 61-70.

Bølviken, B., Bergström, J., Björklund, A., Kontio, M.,
Lehmuspelto, P., Lindholm, T., Magnusson, J., Ottesen, R.T., Steenfelt, A. \& Volden, T. 1986. Geochemical Atlas of Northern Fennoscandia. Nordkalott Project, Geological Surveys of Finland, Norway and Sweden.

Boulton, G.S. 1976. The development of geotechnical properties in glacial tills. In: Legget, R.F. (ed.) Glacial till. The Royal Society of Canada, Special Publication 12, 292-303.

Boyle, R.W. 1979. The geochemistry of gold and its deposits. Geological Survey of Canada, Bulletin 280. 584 p.

Campbell, J.E. \& Schreiner, B.T. 1989. Quaternary geology and its implications to gold exploration in the La Ronge and Flin Flon domains, Saskatchewan. In: DiLabio, R.N.W. \& Coker, W.B. (eds.) Drift Prospecting. Geological Survey of Canada, Paper 89-20, 113-126.

Dreimanis, A. 1976. Tills, their origin and properties. In: Legget, R. F. (ed.) Glacial till. The Royal Society of Canada, Special Publication 12, 11-49.

Dreimanis, A. 1989. Tills, their genetic terminology and classification. In: Goldthwait, R.P. \& Matsch, C.L. (eds.) Genetic Classification of Glacigenic Deposits. Rotterdam: A. A. Balkema, 15-81.

Dreimanis, A. 1990. Formation, deposition, and identification of subglacial and supraglacial tills. In: Kujansuu, R. \& Saarnisto, M. (eds.) Glacial Indicator Tracing. Rotterdam: A. A. Balkema, 35-55.

Eronen, M. 1974. The history of Litorina Sea and associated holocene events. Commentationes Physico-Mathematicae 44: 4, 79-195.

Gleeson, C.F., Rampton, V.N., Thomas, R.D. \& Paradis, S. 1989. Effective mineral exploration for gold using geology, Quaternary geology and exploration geochemistry in areas of shallow till. In: DiLabio, R.N.W. \& Coker, W.B. (eds.) Drift Prospecting. Geological Survey of Canada, Paper 89-20, 71-96.

Glückert, G. 1973. Two large drumlin fields in Central Finland. Fennia 120, 1-37.

Gustavsson, N., Noras, P. \& Tanskanen, H. 1979. Seloste geokemiallisen kartoituksen tutkimusmenetelmistä. Summary: Report on geochemical mapping methods. Geological Survey of Finland, Report of Investigation 39. $20 \mathrm{p}$.

Hartikainen, A. \& Nurmi, P. 1993. Till geochemistry in gold exploration in the late Archean Hattu schist belt, Ilomantsi, eastern Finland. Geological Survey of Finland, Special Paper 17, 273-289.

Hättestrand, C. 1997. Ribbed moraines in Sweden - distribution pattern and palaeoglaciological implications. In: Piotrowski, J.A. (ed.) Subglacial environments. Sedimentary Geology 111, 41-56.

Hirvas, H. 1989. Application of glacial geological studies in prospecting in Finland. In: DiLabio, R.N.W. \& Coker, W.B. (eds.) Drift Prospecting. Geological Survey of Canada, Paper 89-20, 1-6.

Hirvas, H. 1991. Pleistocene stratigraphy of Finnish Lapland. Geological Survey of Finland, Bulletin 354. 123 p.

Hirvas, H., Alftan, A., Pulkkinen, E., Puranen, R. \& Tynni, R. 1977. Raportti malminetsintää palvelevasta maaperätutkimuksesta Pohjois-Suomessa vuosina 1972- 
1976. Summary: A report on glacial drift investigations for ore prospecting purposes in northern Finland 19721976. Geological Survey of Finland, Report of Investigation $19.54 \mathrm{p}$.

Hirvas, H. \& Nenonen, K. 1990. Field methods for glacial indicator tracing. In: Kujansuu, R. \& Saarnisto, M. (eds.) Glacial Indicator Tracing. Rotterdam: A. A. Balkema, 217-247.

Hyyppä, E. 1966. The Late-Quaternary land uplift in the Baltic sphere and the relation diagram of the raised and tilted shore levels. Annales Academiae Scientiarum Fennicae A III 90, 153-168.

Ignatius, H., Korpela, K. \& Kujansuu, R. 1980. The deglaciation of Finland after 10000 B.P. Boreas 9, 217-228.

Koivisto, T. 1992. Discovery of a $\mathrm{Cu}-\mathrm{Au}$ mineralization by step-by-step proceeding till geochemical study in humid hilly peneplain. In: Kauranne, K, Salminen, R. \& Eriksson, K. (eds.) Handbook of Exploration Geochemistry, vol. 5; Regolith exploration geochemistry in arctic and temperate terrains. Netherlands: Elsevier, 302-310.

Koljonen, T. (ed.) 1992. The geochemical atlas of Finland, Part 2: Till. Geological Survey of Finland. 218 p.

Korpela, K. 1969. Die Weichsel-Eiszeit und ihr Interstadial in Peräpohjola (nördliches Nordfinnland) im Licht von submoränen Sedimenten. Annales Academiae Scientiarum Fennicae A III 99. 108 p.

Lintinen, P. 1995. Origin and physical characteristics of till fines in Finland. Geological Survey of Finland, Bulletin $379.83 \mathrm{p}$.

Lundqvist, J. 1969. Problems of the so-called Rogen moraine. Sveriges Geologiska Undersökning C 648, 1-32.

Lundqvist, J. 1989. Rogen (ribbed) moraine - identification and possible origin. In: Menzies, J. \& Rose, J. (eds.) Subglacial bedforms - drumlins, Rogen moraine and associated subglacial bedforms. Sedimentary Geology 62, 281-292.

Lundqvist, J. 1997. Rogen moraine - an example of twostep formation of glacial landscapes. Sedimentary Geology $111,27-40$.

McClenaghan, M.B. 1992. Surface till geochemistry and implications for exploration, Black River-Matheson area, northeastern Ontario. Exploration and Mining Geology 1, 327-337.

McClenaghan, M.B., Lavin, O.P., Nichol, I. \& Shaw, J. 1992. Geochemistry and clast lithology as an aid to till classification, Matheson, Ontario, Canada. Journal of Geochemical Exploration 42, 237-260.

Mikkola, A. 1947. The Vähäjoki iron ore in Tervola, northern Finland. Bulletin de la Commission géologique de Finlande 140, 261-280.

Nichol, I., Lavin, O.P., McClenaghan, M.B. \& Stanley, C.R. 1992. The optimization of geochemical exploration for gold using glacial till. Exploration and Mining Geology $1,305-326$.

Nikkarinen, M. 1991. Size, form and composition of gold grains in glacial drift in Ilomantsi, eastern Finland. Journal of Geochemical Exploration 39, 295-302.

Okko, V. 1941. Über das Verhältnis der Gesteinszusam- mensetzung der Moräne zum Felsgrund in den Gebieten der Kartenblätter von Ylitornio und Rovaniemi im nördlichen Finnland. Geologische Rundschau 32, 627-643.

Okko, V. 1944. Moränenuntersuchungen im westlichen Nordfinnland. Bulletin de la Commission géologique de Finlande 131. 46 p.

Perttunen, V. 1989. Peräpohjolan alueen vulkaniitit; Lapin vulkaniittiprojektin raportti. Summary: Volcanic rocks in the Peräpohja area, northern Finland; A report of the Volcanite Project. Geological Survey of Finland, Report of Investigation $92.40 \mathrm{p}$.

Perttunen, V. 1991. Kemin, Karungin, Simon ja Runkauksen kartta-alueiden kallioperä; Suomen geologinen kartta 1:100 000, kallioperäkarttojen selitykset: lehdet 2541, $2542+2524,2543$ ja 2544. Summary: Pre-Quaternary rocks of the Kemi, Karunki, Simo and Runkaus mapsheets areas. Geological map of Finland 1:100 000. Espoo: Geological Survey of Finland. 80 p.

Peuraniemi, V. 1982. Geochemistry of till and mode of occurrence of metals in some moraine types in Finland. Geological Survey of Finland, Bulletin 322.75 p.

Peuraniemi, V. 1990. Heavy minerals in glacial material. In: Kujansuu, R. \& Saarnisto, M. (eds.) Glacial Indicator Tracing. Rotterdam: A. A. Balkema, 165-185.

Peuraniemi, V. 1991. Geochemistry of till and humus in the Kotkajärvi Cu-Co-Au prospect, Kalvola, southern Finland. Journal of Geochemical Exploration 39, 363-378.

Rainio, H. \& Lahermo, P. 1976. Observations on dark grey basal till in Finland. Bulletin of the Geological Society of Finland 48, 137-152.

Rainio, H. \& Lahermo, P. 1984. New aspect on the distribution and origin of the so-called dark till. In: Köningsson, L.-K. (ed.) Ten years of Nordic till research. Striae 20, 45-47.

Rouhunkoski, P. \& Isokangas, P. 1974. The copper-gold vein deposit of Kivimaa at Tervola, N-Finland. Bulletin of the Geological Society of Finland 46, 29-35.

Salminen, R. 1980. On the geochemistry of copper in the Quaternary deposits in the Kiihtelysvaara area, North Karelia, Finland. Geological Survey of Finland, Bulletin 309.48 p.

Salminen, R. (ed.) 1995. Alueellinen geokemiallinen kartoitus Suomessa vuosina 1982-1994. Summary: Regional Geochemical Mapping in Finland in 1982-1994. Geological Survey of Finland, Report of Investigation 130, 47 p., 24 app.

Salminen, R. \& Tarvainen, T. 1995. Geochemical mapping and databases in Finland. Journal of Geochemical Exploration 55, 321-327.

Sarala, P., Aario, R. \& Peuraniemi, V. 1996. Glacial geology and till geochemical exploration in southern Finnish Lapland. Abstracts: The 22nd Nordic Geological Winter meeting ' 96 , p. 184.

Shilts, W.W. 1984. Till geochemistry in Finland and Canada. Journal of Geochemical Exploration 21, 95-117.

Sibbick, S.J. \& Fletcher, W.K. 1993. Distribution and behavior of gold in soils and tills at the Nickel Plate Mine, southern British Columbia, Canada. Journal of Geochemical Exploration 47, 183-200. 